\title{
The Eocene Hieroglyphic Beds of the Silesian Nappe in the Western Polish Carpathians - their development and foraminiferal record
}

\author{
Anna WAŚKOWSKA ${ }^{1, *}$ \\ 1 AGH University of Science and Technology, Faculty of Geology, Geophysics and Environmental Protection, al. A. Mickiewi- \\ cza 30, 30-059 Kraków, Poland
}

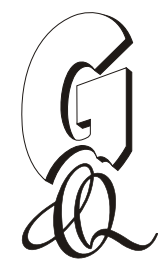

\begin{abstract}
Waśkowska, A., 2015. The Eocene Hieroglyphic Beds of the Silesian Nappe in the Western Polish Carpathians - their development and foraminiferal record. Geological Quarterly, 59 (2): 271-299, doi: 10.7306/gq.1213

The sedimentation of Hieroglyphic Beds of the Silesian Nappe took place from the Early Eocene up to Late Eocene within the Carpathian Silesian Basin. These beds are dominated by thin-bedded flysch containing - at various stratigraphic positions thick sandstone-free complexes with variegated shales or bentonite laminae developed during a limited supply of material from the land. Their variability and boundary sequences are presented. In general, their lithological heterogeneity is connected by the ratio of sandstones and shales, thickness of layers and occurrence of different type of shales. The Hieroglyphic Beds are underlain by the Ciężkowice Sandstone or directly by the Istebna Beds and overlain by the Globigerina Marls or directly by the Menilite Beds. In the Ypresian, during the sedimentation of Hieroglyphic Beds, foraminiferal associations with numerous small-sized Trochammina developed in the Silesian Basin after the PETM crisis. Since the Lutetian, more diverse associations occurred in slightly more favourable conditions, with Reticulophragmium amplectens (Grzybowski), Dolgenia latus (Grzybowski), and Reticulophragmium gerochi Neagu et al., which preferred cool waters, and are index fossils for stratigraphy. The Hieroglyphic Beds developed during a period of gradually cooling global climate. The gradual decrease in temperature stimulated the transfer of species. The thermophilous forms, whose optimum development took place in the Late Cretaceous-Paleocene, disappear during Lower and Middle Eocene and new species that preferred cold boreal waters commonly occur in Middle and Late Ecocene. A profound restructuring of foraminiferal assemblages took place in the Priabonian, when massive numbers of calcareous benthic and planktonic forms were deposited.
\end{abstract}

Key words: Hieroglyphic Beds, Silesian Nappe, Outer Carpathians, Eocene, foraminifera, lithostratigraphy.

\section{INTRODUCTION}

The Eocene was a time of tectonic reorganization in the Tethys Ocean. In the western part of the Tethys this reorganization was associated with changes in the configuration and bathymetry of the Carpathian sedimentary basins (e.g., Książkiewicz, 1962,1965, 1972, 1977; Mahel', 1974; Unrug, 1979; Cieszkowski et al., 1985, 2009; Ślączka and Kaminski, 1998; Lexa et al., 2000; Ryłko, 2004; Golonka et al., 2006, 2008, 2013; Olszewska and Malata, 2006; Oszczypko et al., 2006; Słomka et al., 2006; Ślączka et al., 2006; Golonka, 2011). At that time, thin-bedded flysch deposits formed in the Carpathian basins, covering large areas of the sea-floor. Some of them constitute the so-called Hieroglyphic Beds composing a complex of turbidite formations, generally with predominant shales. Great numbers of hieroglyphs can be found on the bottom surfaces of thin-bedded sandstones, which are the characteristic feature of these layers (e.g., Paul and Tietze, 1879;

\section{*E-mail: waskowsk@agh.edu.pl}

Received: October 9, 2014; accepted: December 1, 2014; first published online: January 22, 2015
Świdziński, 1948; Książkiewicz, 1951; Geroch et al., 1967; Czaplicka et al., 1968; Paul, 1993).

Under this name, the division functions as an informal lithostratigraphic unit in separate Carpathian tectonic units, i.e., in the Silesian, Skole, and Subsilesian nappes, and in the Fore-Magura group of nappes (e.g., Świdziński, 1948; Książkiewicz, 1951; Geroch et al., 1967; Jurkiewicz, 1967; Ślączka, 1971; Burtan, 1978; Morgiel and Szymakowska, 1978; Golonka et al., 1979, 2013; Rajchel, 1990; Neścieruk et al., 1996; Ryłko, 2004; Golonka and Waśkowska-Oliwa, 2007). In the Silesian Nappe, this type of deposits occurs beneath the Globigerina Marls and Menilite Beds, and above the Ciężkowice Sandstone and Istebna Beds. The Hieroglyphic Beds represent a standard lithostratigraphic unit, depicted as a separate unit in cartographic works (e.g., SkoczylasCiszewska, 1954; Burtan and Szymakowska, 1964; Książkiewicz, 1974a, b; Golonka, 1981; Szymakowska and Wójcik, 1981,1992; Cieszkowski et al., 1991; Paul et al., 1996) or in combination with Green and/or Variegated Shales (e.g., Żytko, 1963; Nowak, 1963, 1964; Sikora, 1963; Burtan, 1964a, b; Burtan and Skoczylas-Ciszewska, 1964a, b, c; Szymakowska and Żytko, 1964; Golonka et al., 1979; Neścieruk et al., 1995). Despite the common use of this lithostratigraphic unit, it still lacks any wider documentation, apart from general characteristics (e.g., Geroch, 1960; Bieda et al., 1963; Geroch et al., 1967; Neścieruk et al., 1996; Ryłko, 2004; Cieszkowski et al., 2006a; 
Chodyń and Waśkowska-Oliwa, 2006; Waśkowska et al., 2008). Micropalaeontological data pertaining to the Hieroglyphic Beds of the Silesian Nappe (e.g., Jurkiewicz, 1959, 1967; Geroch, 1960; Bieda et al., 1963; Geroch et al., 1967; Książkiewicz, 1974b; Geroch and Koszarski, 1988; Cieszkowski, 1992; Szymakowska and Wójcik, 1992; Chodyń and Waśkowska-Oliwa, 2006; Waśkowska, 2012, 2014a, b, c; Waśkowska and Cieszkowski, 2014) are still scarce. The majority of references mention only characteristic forms, or refer to single foraminiferal species and constitute only minor parts of comprehensive biostratigraphic-lithostratigraphic accounts of the deposits of the Silesian Nappe. The sedimentation of the Hieroglyphic Beds occurred in deep-water sedimentary zones of the Carpathian Basin during essential palaeoclimatic changes linked with intense climate cooling (e.g., Coxall et al., 2005; Agnini et al., 2006; Bijl et al., 2010; Galazzo et al., 2013 and papers cited therein). Therefore, studying the variability within continuous profiles of the Hieroglyphic Beds seemed to be an issue worthy of detailed investigation. This was the motivation behind undertaking more detailed analyses based on already published data. In recent years, changes have taken place within the taxonomy of foraminifera. Apart from redefinitions of species, new forms have also been described, identified in samples from the Hieroglyphic Beds (Waśkowska-Oliwa, 2008; Waśkowska, 2014a, b, c). Branches of palaeoecology have developed to provide possibilities for wider interpretations.

The present study focuses on the lithological development and its heterogeneity in the Hieroglyphic Beds of the Silesian Nappe in the western sector of the Outer Carpathians, as well as on the variability in the foraminiferal record.

\section{STUDY AREA}

Studies were conducted within the Outer Carpathians, which are composed predominantly of turbidite deposits developed in basins of the North-Western Tethys. The Carpathian deposits are chiefly of a deep-water type and developed during the Mesozoic and Cenozoic times. One of the Tethys basins is the Silesian Basin sensu lato, which evolved during its 150 million years of existence, changing its extent, morphology and configuration (e.g., Książkiewicz, 1962, 1965, 1972, 1977; Unrug, 1979; Cieszkowski et al., 1985; Słomka, 1995; Ślączka and Kaminski, 1998; Ślączka et al., 2006; Golonka et al., 2006, 2013; Olszewska and Malata, 2006; Oszczypko, 2006; Ryłko, 2004; Słomka et al., 2006; Golonka and Waśkowska-Oliwa, 2007). The Jurassic-Lower Cretaceous sediments were deposited in one of the two main Carpathian basins, called the Protosilesian Basin. This basin includes early stages of deep-sea basin development. The Upper Cretaceous-Lower Paleogene deposits accumulated in the Silesian Basin sensu stricto, which emerged as a result of geotectonic reorganization via dividing the basin from the Protosilesian Basin. On the other hand, the Late Paleogene and Early Neogene formations were deposited in the Krosno-Menilitie Basin, which - after the next reorganization of the architecture of the Carpathian basins, associated with the disappearance of cordilleras - represents the declining phases of the evolution. In the Miocene, a complicated process of orogeny resulted in the disappearance of the Carpathian basins, and the deposits accumulated in the basins became the constituents of the Carpathian nappes that subsequently emerged.

The Outer Carpathians have a nappe-type structure (e.g., Nowak, 1927; Świdziński, 1948; Książkiewicz, 1962, 1965, 1972, 1977; Geroch et al., 1967; Mahel', 1974; Eliaš, 1979;
Cieszkowski et al., 1985; Żytko et al., 1989; Słomka, 1995; Ślączka and Kaminski, 1998; Golonka and Waśkowska, 2007; Golonka et al., 2013; Fig. 1). Among the Outer Carpathian nappes, the central position is occupied by the Silesian Nappe. Its deposits were accumulated mainly in the Silesian Basin sensu lato.

The Hieroglyphic Beds were studied in the area between the Ropa River valley to the east, and the Olza River valley to the west. The study covers four sectors in the Silesian Nappe. Starting from the east, these are: the Beskid Niski Mountains, Rożnów Foothills, Wiśnicz Foothills, and the Beskid Śląski Mountains (Fig. 1). Representative, fairly complete profiles of the Hieroglyphic Beds were selected from each sector, having original lower and upper boundaries with the under- and overlying divisions preserved. In the eastern sector, the complete profile is situated in the town of Gorlice, in the Sękówka River valley (Fig. 2). Next, in the Rożnów Foothills area, the Hieroglyphic Beds and Green Shales occur in an area adjacent to the eastern shore of Rożnów Lake. In this area, the outcrops of Hieroglyphic Beds were analysed in the Gródek-Lipie area, whereas a profile in the Szczecinówka Stream valley was selected for detailed study (Fig. 2). In the Wiśnicz Foothills, outcrops located between Zegartowice and Szczyrzyc were analysed. A detailed analysis was carried out on a complete profile situated in the valley of the Stradomka River and its tributaries in Krzesławice and Pogorzany (Fig. 2). In the westernmost sector, which included outcrops in the Beskid Śląski Mountains, the Hieroglyphic Beds were analysed in the Jasnowice, Istebna, and Kamesznica areas. A complete profile is available in the Olecka Stream valley, in the border zone between Poland and the Czech Republic (Fig. 2).

\section{METHODS AND MATERIALS}

The research was based on field work which consisted of prospecting, detailed profiling and micropalaeontological sampling of the Hieroglyphic Beds in the selected regions described above. Material for micropalaeontological analysis was prepared according to standard procedures, involving maceration in an aquatic solution of Glauber's salt, and washing on $0.068 \mathrm{~mm}$ sieve meshes. From the subsequent portions of residue obtained in this way, all microfossils were separated from the terrigenous material and subjected to verification. For the purpose of micropalaeontological study, 105 samples from the Hieroglyphic Beds were selected. The microfossils were dominated by foraminifera, including mainly agglutinated forms, whereas fish teeth occurred as an accessory component. In calcareous deposits, echinoid spines and fragments of molluscan shells were found. The faunal specimens were in a fairly good preservation state. The microfaunal analysis pertained only to the foraminiferal group.

The material was analysed under a NIKON VL100POL binocular microscope at the Department of General Geology and Geotourism of the Faculty of Geology, Geophysics and Environmental Protection, AGH University of Science and Technology (WGGiOŚ AGH), and a FEI QUANTA 200 FEG scanning microscope at the Scanning Microscopy Laboratory of WGGiOŚ in Kraków.

The analysed materials have been deposited in the author's collection at the Department of General Geology and Geotourism of the Faculty of Geology, Geophysics and Environmental Protection, AGH University of Science and Technology in Kraków. 


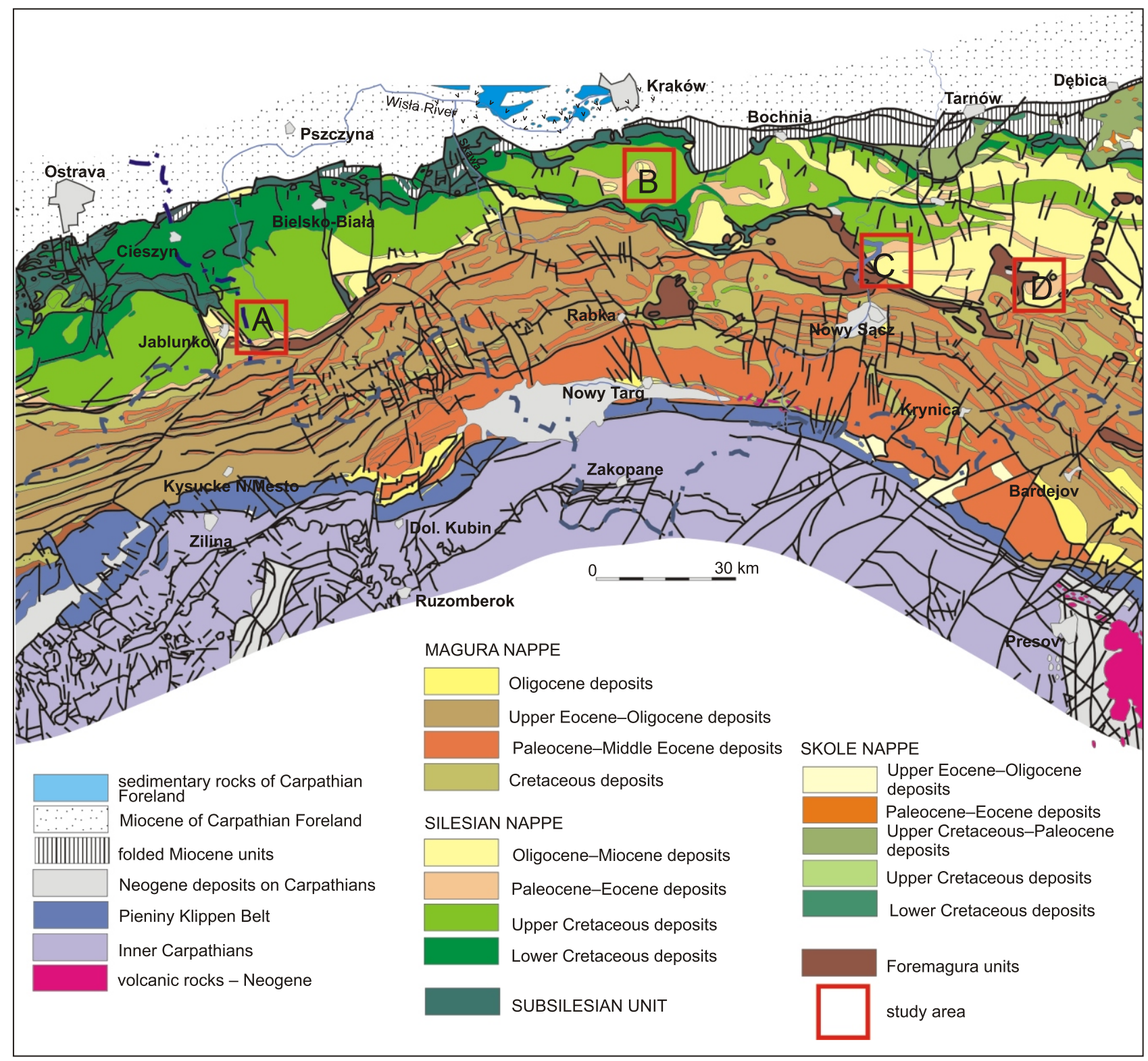

Fig. 1. Study areas on the background of the Western Carpathians geological map (after Lexa et al., 2000, simplified)

\author{
A - Beskid Niski Mts., B - Rożnów Foothils, C - Wiśnicz Foothils, D - Beskid Śląski Mts.
}

\section{LITHOLOGICAL DEVELOPMENT AND FORAMINIFERA}

\section{BESKID NISKI MTS. - GORLICE AREA}

Lithology. The Hieroglyphic Beds occur between the Ciężkowice Sandstone and the Globigerina and Menilite Beds (Sikora, 1964; Szymakowska, 1979), attaining a thickness of more than 200 m (Waśkowska, 2014a; Fig. 3). Their base is sharp and the natural transition into the Hieroglyphic Beds is distinctly marked in the profile. The boundary interval consists of the last compact complex of thick- and very thick-bedded noncalcareous Ciężkowice-type sandstones, above which occurs a shale complex with single beds of laminated sandstones. Szymakowska (1979) described the variegated shales between the Ciężkowice Sandstone and the Hieroglyphic Beds in the Gorlice area. In the lower part of the section, the sandstones are medium-bedded, fine-grained, and towards the top, the beds gradually decrease in thickness and the shale complexes are interbedded by several centimetre thick layers of sandstones. The shales have a dark grey colour. They are laminated by grey shales of lighter colours, and are strongly bioturbated. Sandy shales with muscovite, or harder massive siltstones occur as intercalations. The complex with sandstones reaches a thickness of ca. $60 \mathrm{~m}$. Above it, the Hieroglyphic Beds continue exclusively as sandstone-free deposits represented initially dark-grey and grey bioturbated shales which subsequently pass into grey-green ones with a slightly increased proportion of clay (Fig. 4). In the upper part, some $40 \mathrm{~m}$ from the top, there is a 15 metre thick complex of variegated shales with red shales laminated by green shales containing cream-coloured bentonites (Figs. 3 and 4). In the middle part of the profile, a submarine slump is found with plastically deformed clasts of grey-green shales within the disturbed Hieroglyphic deposits. The transition of Hieroglyphic Beds into the overlying 

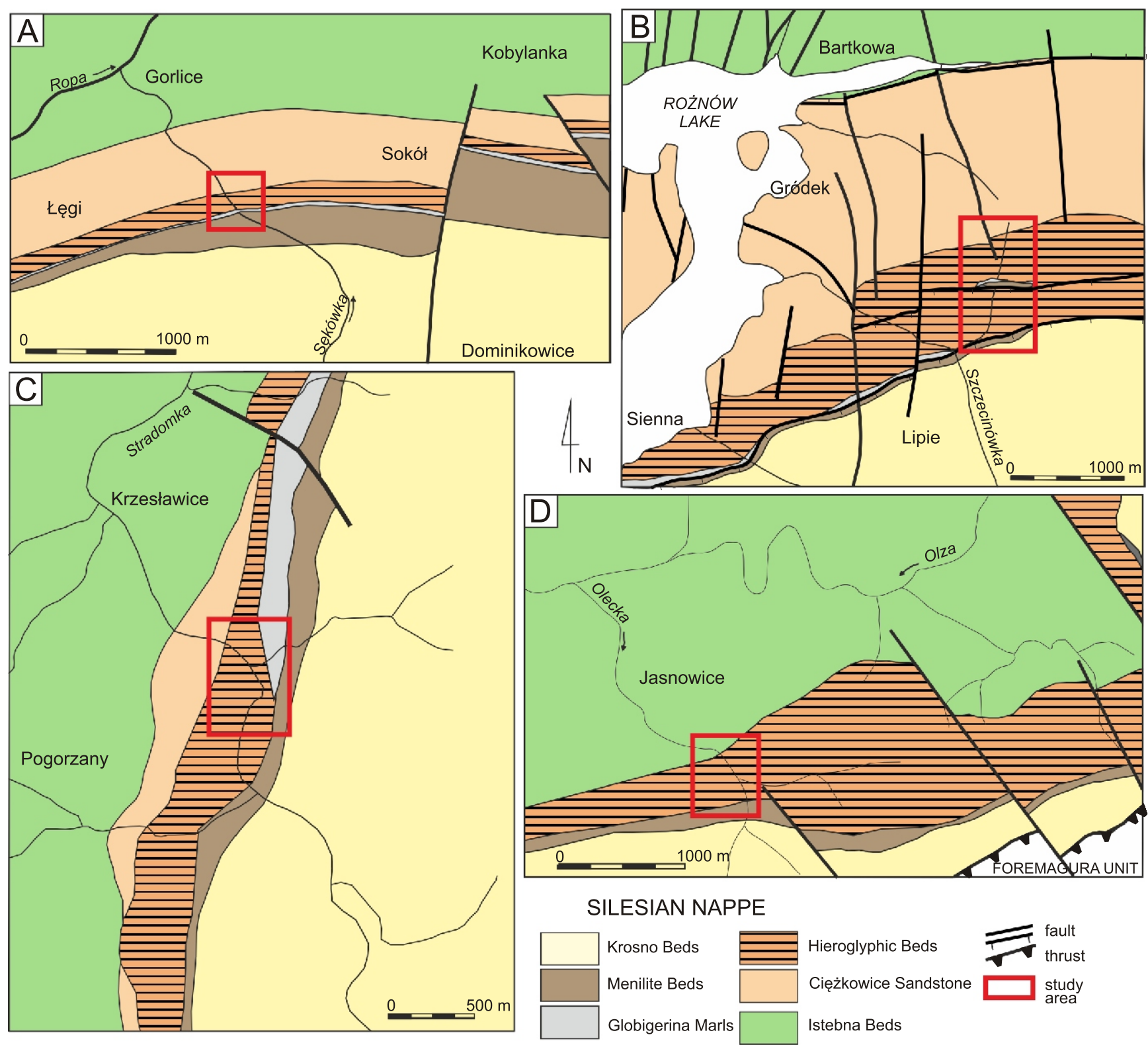

Fig. 2. Detailed geological maps with locations of the study areas: A - Beskid Niski Mts. (after Szymakowska, 1979, modified), B - Rożnów Foothils (after Cieszkowski, 1992, modified), C - Wiśnicz Foothils (after Burtan, 1974, modified), D - Beskid Śląski Mts. (after Burtan, 1972, modified)

Globigerina and Menilite Beds is distinctly marked in the profile (Fig. 4). Among the grey-green shales, characteristic of the Hieroglyphic Beds, there are thin layers of brown shales that are characteristic for Menilite Beds, which completely supersede the Hieroglyphic-type shales over ca. one metre of the profile. The first thin beds of grey marls/marly Globigerina-type limestones are found at this level.

Foraminiferal record and biostratigraphical age. The lower part of the Hieroglyphic Beds contains an uncharacteristic fauna comprised predominantly of cosmopolitan and long-ranged forms (Fig. 3). The most numerous are tubular foraminifera, i.e., Bathysiphon, Psammosiphonella, Rhabdammina, as well as the genera Recurvoides, Thalmannammina, Paratrochamminoides and Trochamminoides. The foraminiferal assemblages from the lowermost part of the Hieroglyphic Beds contains an increased proportion of Trochammina species, and their quantity fluctuates around $20 \%$ of all foraminifera in the assemblage. Single individuals of Caudammina ovula (Grzybowski), C. excelsa (Dylążanka) and Annectina grzybowskii (Jurkiewicz) appear (Fig. 5), which had their last occurrences in the Early Eocene (e.g., Jurkiewicz, 1967; Jednorowska, 1968; Bąk, 2004; Kaminski and Gradstein, 2005; Waśkowska, 2011a, b, 2015a). There is also Popovia beckmanni (Kaminski et Geroch) known from the Paleocene to the Middle Eocene (Kaminski and Geroch, 1987; Kaminski and Gradstein, 2005). From the lower part of the Hieroglyphic Beds, Bieda (1946) reported Nummulites planulatus Lamarck, therefore documenting the Lower Eocene age of this part of the unit. The samples from the upper part, underlying the Hieroglyphic Beds of the Ciężkowice Sandstone, contain assemblages of Glomospira Acme type, with the proportion of Glomospira forms reaching up to $50 \%$. In the deposits of the Outer Carpathians, such assemblages have been found in the Lower Eocene (e.g., Jurkiewicz, 1959, 1967; Morgiel and Szymakowska, 1978; 


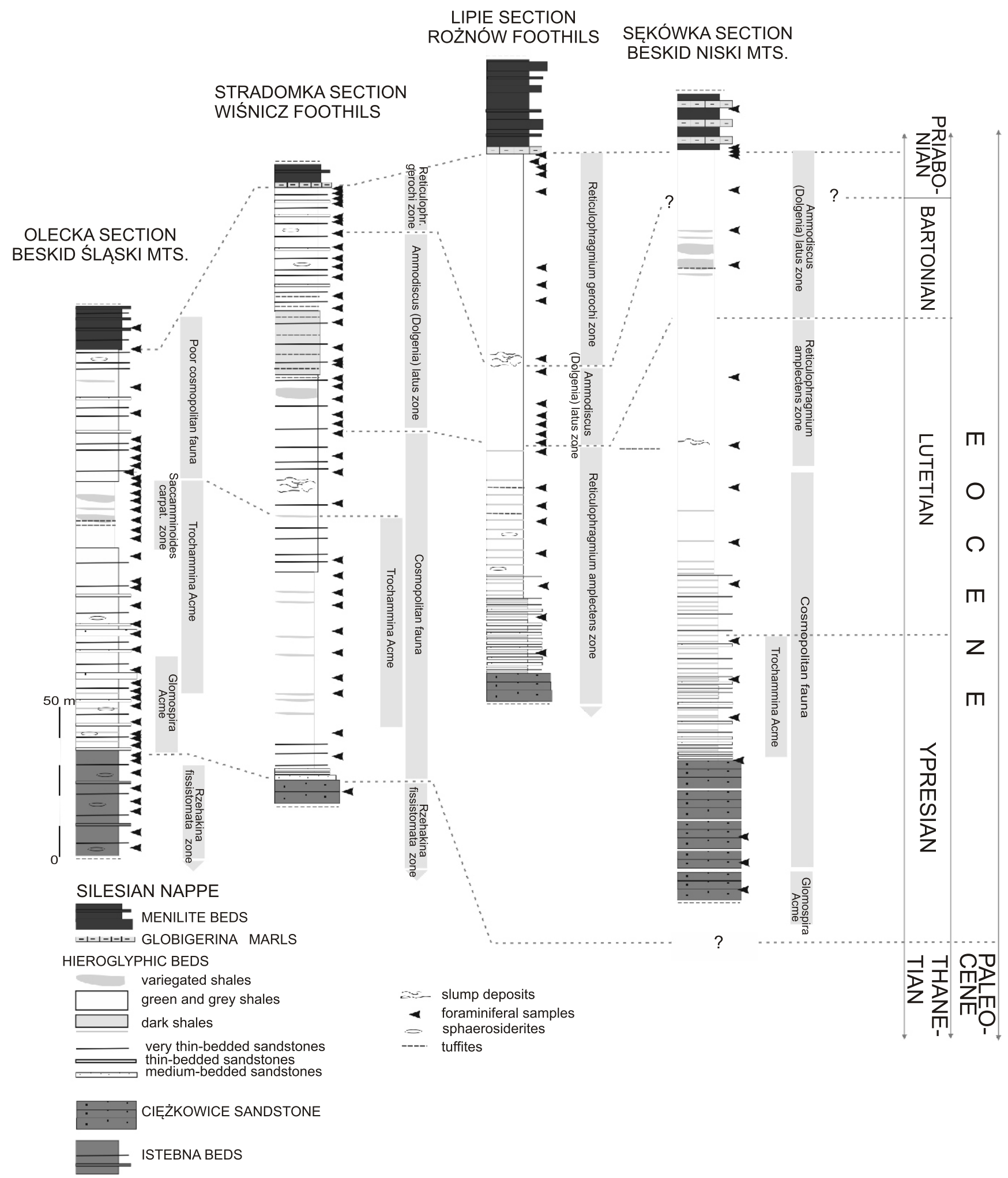

Fig. 3. Biostratigraphy of the Hieroglyphic Beds against schematic lithological logs 

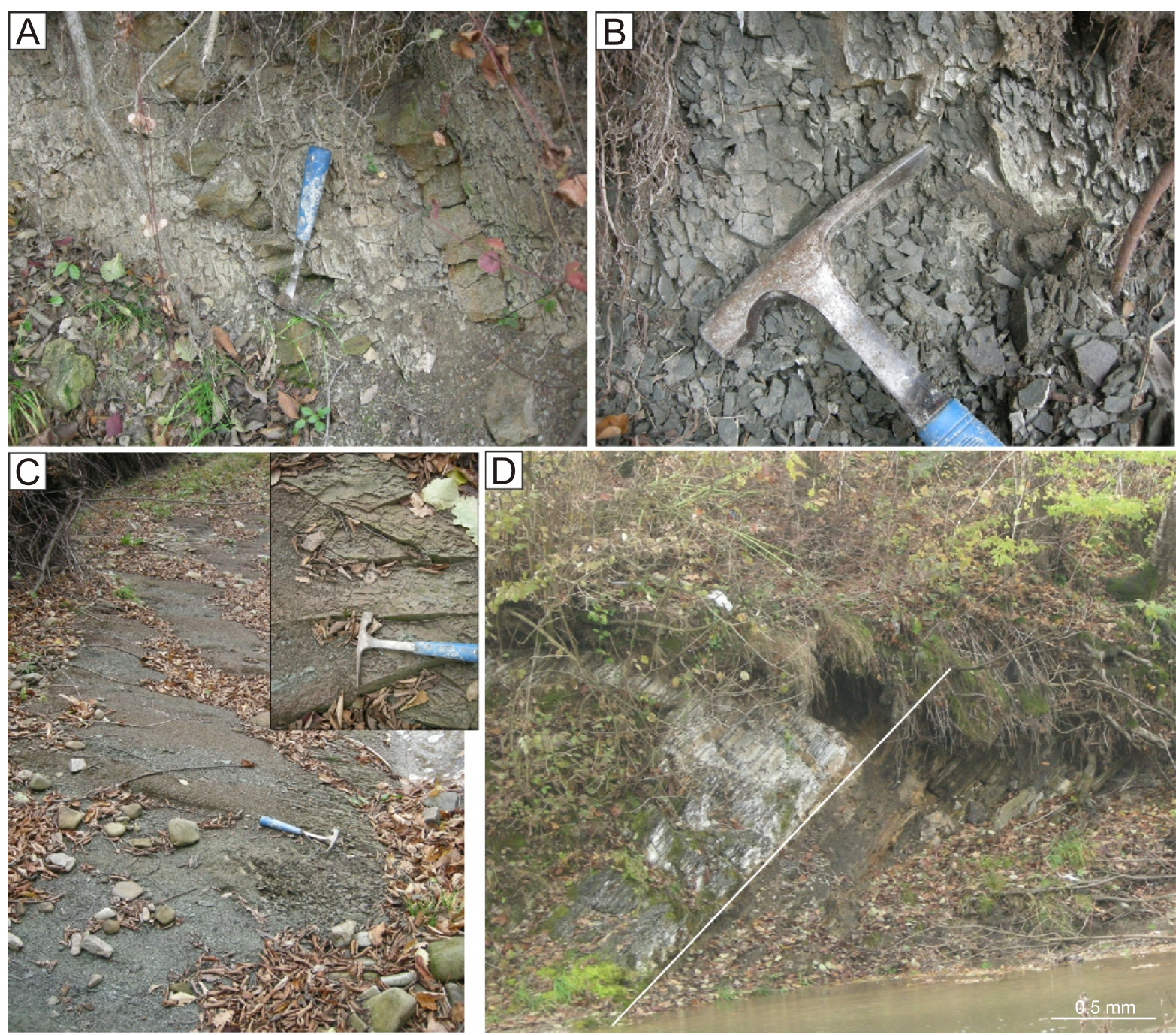

Fig. 4. Images of deposits of the Hieroglyphic Beds and Green Shales in the Gorlice section

A - shaly-sandy deposits of the Hieroglyphic Beds; B - Green Shales deposits; C - variegated shales in upper part of section; D - Hieroglyphic Beds/Menilite Beds transition zone, boundary is marked by line

Olszewska, 1980, 1984, 1997; Morgiel and Olszewska, 1981; Bąk et al., 1997; Waśkowska-Oliwa, 2000, 2005; Bąk, 2004; Cieszkowski et al., 2006b), and their presence may constitute a reference to time frames of the sedimentation of the Hieroglyphic Beds.

More taxonomically diversified assemblages providing the basis for subdividing relevant biostratigraphic zones in the Hieroglyphic Beds occur only in half of the thickness of the shale complex. The first of the distinguishable zones is the Reticulophragmium amplectens zone (Fig. 3). In foraminiferal assemblages, the index taxon co-occurs with Eggerelloides propinqus (Brady), Praesphaerammina subgaleata (Vasicek), Haplophragmoides nauticus Kender, Kaminski et Jones, Buzasina pacifica (Krasheninnikov) (Fig. 5) and Ammolagena clavata (Jones et Parker). The sedimentary interval with the Reticulophragmium amplectes zone contains point occurrences of deposits with redeposited fauna representing an assemblage that is transferred from variegated deposits. Redeposited forms constitute an admixture to the typical Hieroglyphic-type assemblage. Against the grey tests occurring commonly in surrounding deposits, it distinguishes itself by the presence of tests with a characteristic reddish colouration. The redeposited forms include mainly foraminifera with round-shaped tests, e.g., Glomospira and Recurvoides, as well as the species
Caudammina gigantea Geroch, not known to occur in the Eocene, but found in older intervals. In the upper part of the $\mathrm{Hi}-$ eroglyphic Beds, beginning from the level with variegated shales, the index species for the next biostratigraphic zone Ammodicus (Dolgenia) latus Grzybowski is a common element (up to $10 \%$ of the foraminiferal assemblage; Figs. 3 and 5). Among typical Eocene foraminifera, Pseudonodosinella elonagata (Grzybowski), and single individuals of Eratidus gerochi Kaminski et Gradstein and Bulbobaculites gorlicensis Waśkowska (Waśkowska, 2014a) are identified. In the topmost part of the profile, Spirosigmoilinella compressa Matsunaga (Fig. 5) and planktonic foraminifera appear. Large Subbotina specimens, typical of the Eocene, are represented in greatest numbers. Also identified were Thurammina species that are relatively rare in the Carpathian assemblages. The characteristic feature of the assemblages of the upper part of the Hieroglyphic Beds is an increased proportion of Reophax, which fluctuates around $10 \%$ of the assemblage.

\section{ROŻNÓW FOOTHILLS - ROŻNÓW LAKE AREA}

Lithology. Between the Ciężkowice Sandstone and Globigerina and Menilite Beds, there is a complex of deposits made up predominantly of shales (Fig. 3). Above the 


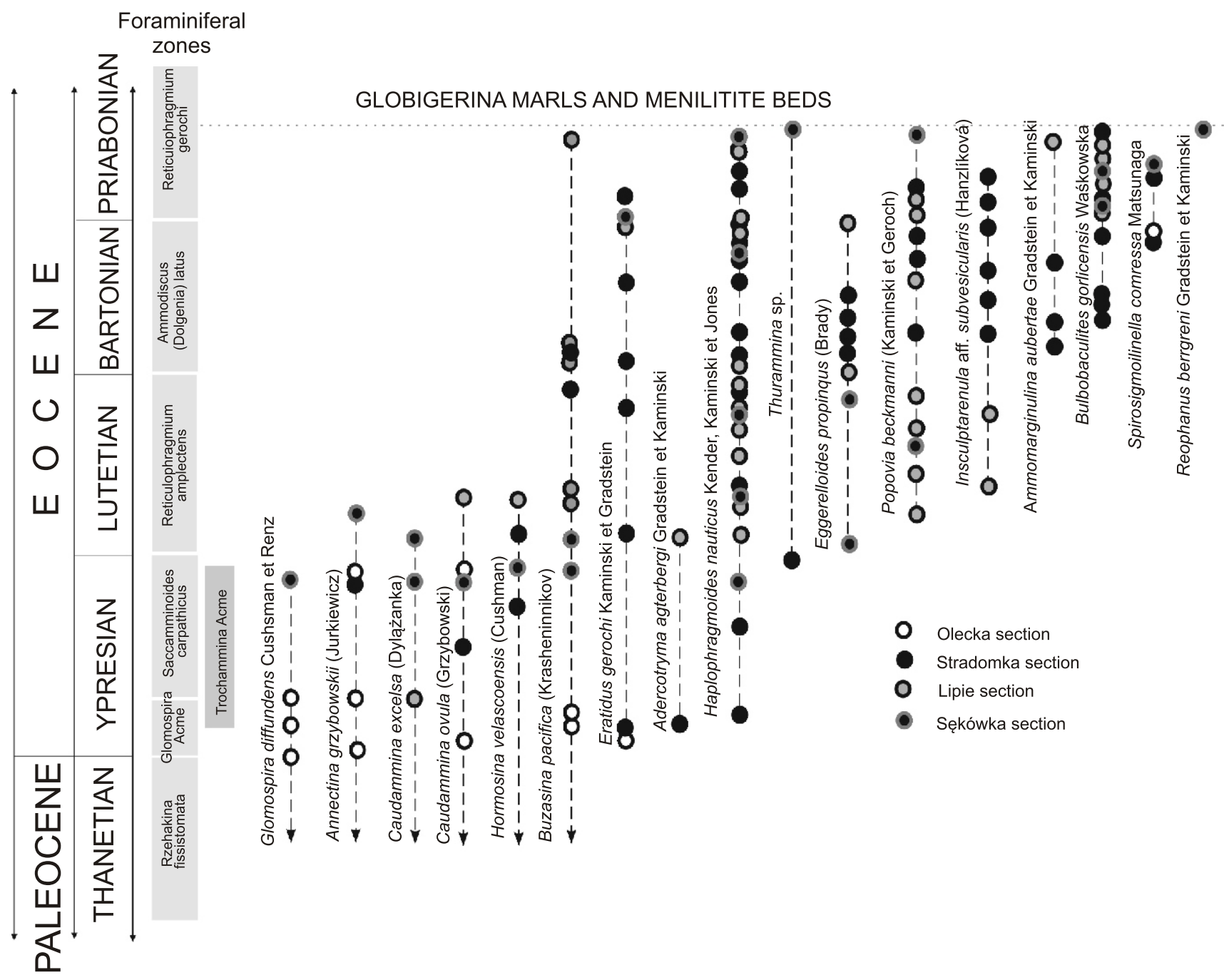

Fig. 5. Distribution of selected foraminiferal species within the Hieroglyphic Beds

Ciężkowice Sandstone complexes, there are ca. $20 \mathrm{~m}$ thick shale-sandstone deposits of the Hieroglyphic Beds with grey laminated sandstones (Fig. 6). They are at first medium- and thin-bedded, then thin-bedded and becoming increasingly rarer until they gradually disappear (Waśkowska, 2014b). Shales are dark grey, at some places partly sandy, and are laminated with paler grey shales. They rarely contain siderite concretions. Above the complex of classic Hieroglyphic Beds there are deposits devoid of sandstone, known as the Green Shales (Figs. 3, 6-8). In the Lipie area, these are ca. $150 \mathrm{~m}$ thick grey and grey-green shales, laminated by darker shales in the lower part, and grading towards the top into grey-green deposits with a distinct increase in the content of clay grains. Among them, single thin layers of bentonite sporadically occur (Waśkowska, 2014b; Fig. 6). The Green Shales includes submarine slump deposits with oval blocks up to $2 \mathrm{~m}$ in diameter, composed of "septarian limestones" in a silty matrix (Cieszkowski, 1992; Cieszkowski and Waśkowska, 2013a, b; Figs. 6 and 8). In the Hieroglyphic-Green Shale Beds of the Rożnów Lake area, there is an extended olistostrome. Its presence results in the increased thickness of this unit locally up to $350 \mathrm{~m}$ (Waśkowska and Cieszkowski, 2014). The contact between the Green Shales and the overlying Globigerina Marls is fairly distinct (Fig. 7) and placed beneath the first bed of grey marly lime- stones typical for Globigerina Marls, or upon the complex of grey-green marly shales if the limestone beds are absent.

Foraminiferal record and biostratigraphical age. The $\mathrm{Hi}-$ eroglyphic Beds and the lower part of the Green Shales contain fauna typical of the Lutetian Reticulophragmium amplectens zone (Fig. 3). The commonly occurring diagnostic taxon, Haplophragmoides nauticus Kender, Kaminski et Jones, is accompanied by Popovia beckmanni (Kaminski et Geroch), Adercotryma agterbergi Gradstein et Kaminski, Buzasina pacifica (Krasheninnikov) and Insculptarenula aff. subvesicularis (Hanzlíková) (Fig. 5) known from the Eocene (Waśkowska, 2014b). In the lower part of this biozone, the last occurrences of Caudammina ovula (Grzybowski) and Hormosina velascoensis (Cushman) are observed (Fig. 5). Sandstone from the upper part of the Ciężkowice Sandstone of the Rożnów Lake area contains numulitic limestone clasts with Nummulites laevigatus (Bruguičre) of the Middle Eocene (Cieszkowski 1992). Next, the middle part of the Green Shale section contains assemblages of the Ammodiscus (Dolgenia) latus zone with Eggerelloides propinqus (Brady) and Bulbobaculites gorlicensis Waśkowska, Buzasina pacifica (Krasheninnikov) (Figs. 3 and 5). An increase in the abundance of Reophax is observed in its middle part. In the topmost part of the Green Shales, Reticulophragmium gerochi Neagu et al. ap- 

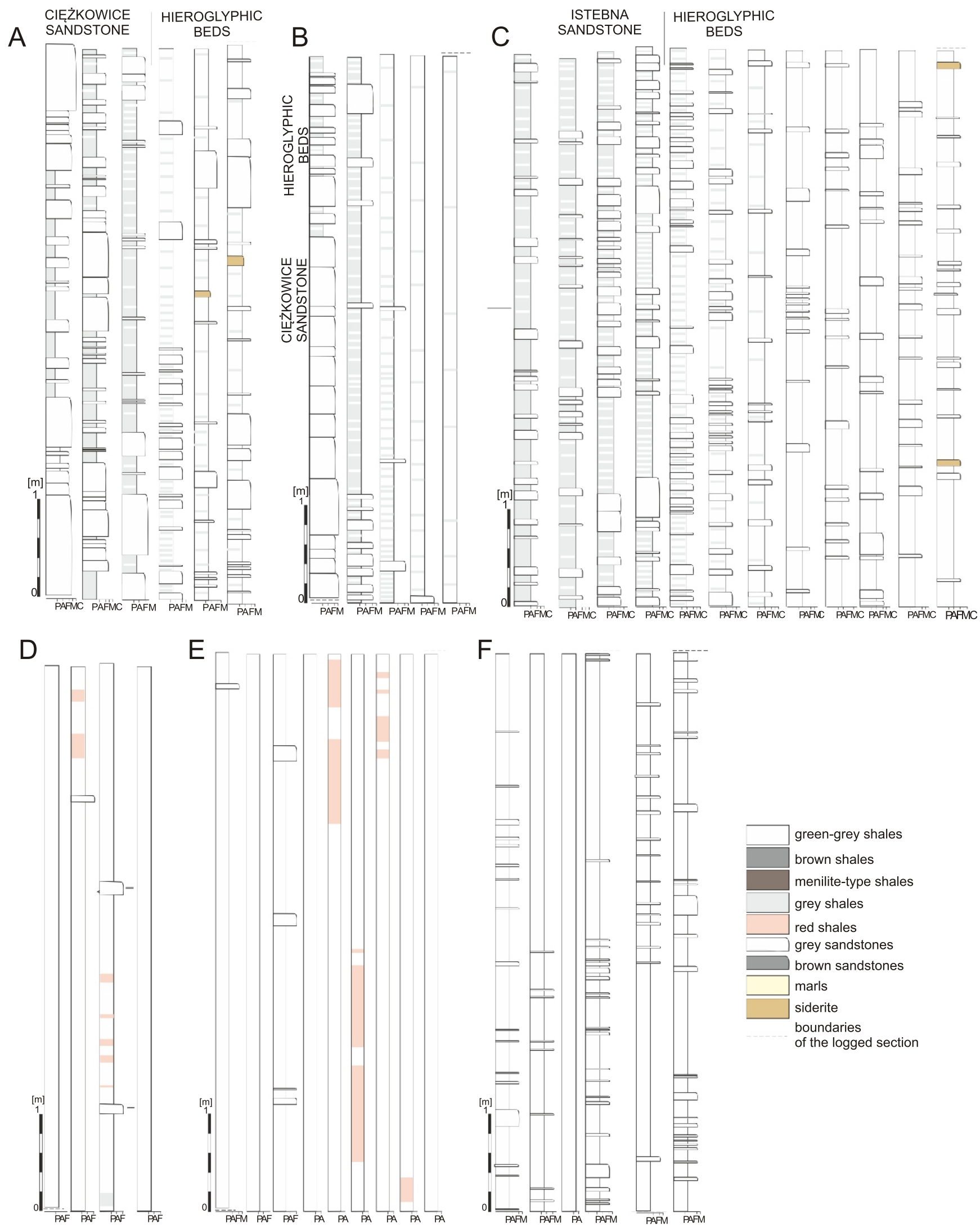

Fig. 6. Lithological logs of the Hieroglyphic Beds - examples

Lowermost part: A - Lipie section; B - Stradomka section; C - Olecka section; D - lower part, Stradomka section; E - middle part, Olecka section; F - upper part, Olecka section; grain size: A - silt, C - coarse sand, F - fine sand, M - medium sand, P - clay 
A

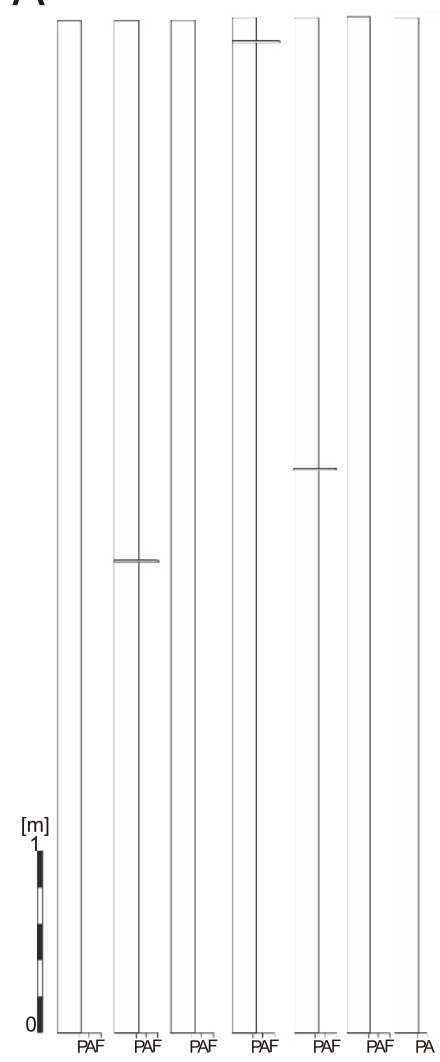

B

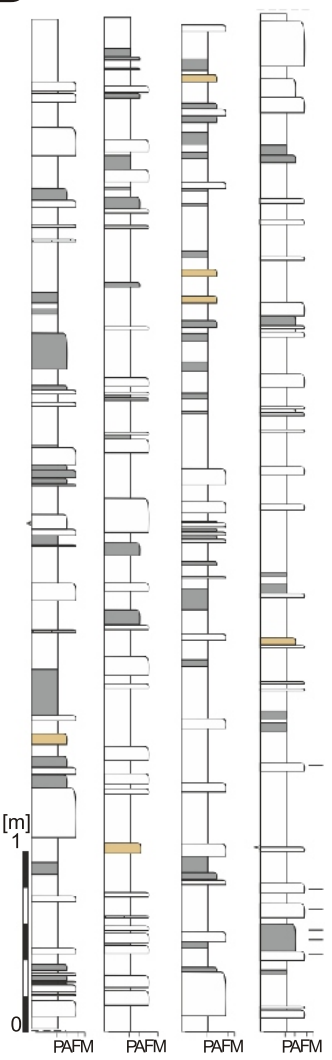

C

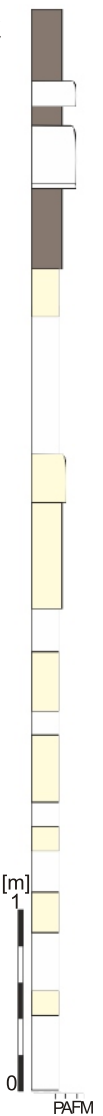

D

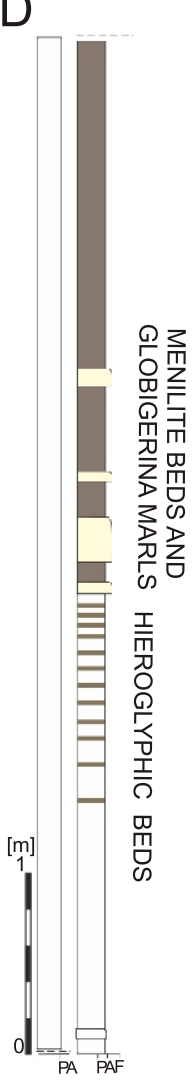

$\mathrm{E}$

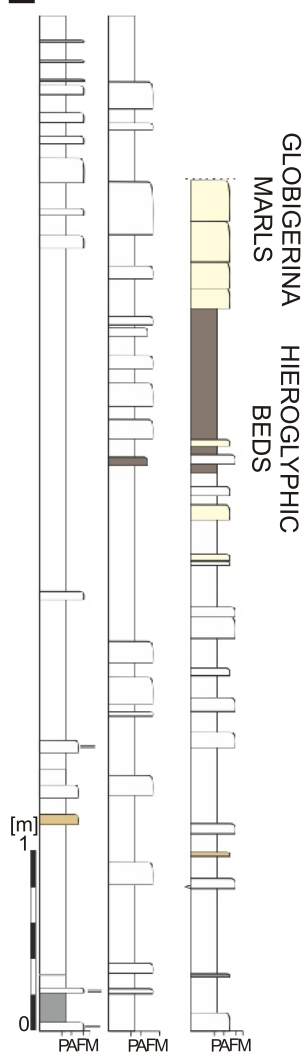

Fig. 7. Lithological logs of the Hieroglyphic Beds - examples

A - lower part of the green shales, Lipie section; B - upper part, Stradomka section; uppermost part: C - Lipie section, D - Gorlice section, Stradomka section; other explanation see Figure 6

pears ephemerally, therefore marking the Prabonian Reticulophragmium rotundidorsatum (=gerochi) zone (Fig. 3). In the uppermost part of the Green Shales, the abundance and diversity of planktonic foraminifera belonging mainly to the genus Subbotina, as well as of the calcareous benthos of Eponides-Cicicides morphotypes increase dramatically (Waśkowska, 2014b).

\section{WIŚNICZ FOOTHILS - SZCZYRZYC AREA}

Lithology. As in other sections, the Hieroglyphic Beds, up to $200 \mathrm{~m}$ thick, occur above the Ciężkowice Sandstone (Fig. 3). Their lower boundary is distinct. A ca. $3 \mathrm{~m}$ thick transitional series occurs under the last compact complex of thick-bedded sandstones of the Ciężkowice type. It starts with medium- and thin-bedded sandstones, followed by thin-bedded grey sandstones (Waśkowska, 2015b; Fig. 6). The lower part of the Hieroglyphic Beds, which constitutes ca. one-third of the profile, consists of deposits devoid of sandstone, represented by strongly bioturbated grey-green shales with intercalations of red shales (Fig. 9), rarely and irregularly distributed in the profile. Above it, there are thin- and medium-bedded quartzose sandstones, with parallel or wavy lamination and numerous hieroglyphs, mainly trace fossils. In the lower part, two complexes of variegated shales as well as a $10 \mathrm{~m}$ thick subaqueous slump were found (Waśkowska, 2015b; Figs. 3, 6 and 9). Clasts of shales, sandstones similar to those from the Istebna Beds, and thin-bedded flysch deposits occur in the matrix. Within the shale-sandstone profile, there is a ca. $20 \mathrm{~m}$ thick complex of predominantly brown and brown-grey shales laminated by grey-green shales (Figs. 3 and 9). Its characteristic feature is the presence of numerous thin layers of cream-coloured bentonites, maybe of pyroclastic origin. This complex has the characteristics of "the Black Eocene-type" deposits (Waśkowska, 2015b). Above it, sporadic carbonate concretions are observed in shale-sandstone deposits. The transition into the overlying deposits of the Globigerina Beds is evident. The transition zone has a thickness of ca. $1.5 \mathrm{~m}$. Within this zone, single thin beds of grey marly Globigerina limestones are present, with the co-occurrence of dark shales characteristic of the Menilite Beds (Fig. 7).

Foraminiferal record and biostratigraphic age. The lower and middle parts of the Hieroglyphic Beds (shale complex and thin-bedded flysch beneath "the Black Eocene-type" deposits) contain a nondiagnostic cosmopolitan deep-water foraminiferal assemblage (Fig. 3). It occurs in the deposits corresponding to the Lower and Middle Eocene. Identification of foraminiferal zones is difficult in this interval because of the presence of chiefly long-ranged species and the lack of index species that determine adequate biostratigraphic intervals in accordance with the zonal definitions. The estimated Early and Middle Eocene age is predetermined by the presence of forms whose biostratigraphic ranges reach the Early Eocene, namely Annectina grzybowskii (Jurkiewicz) (e.g., Jurkiewicz, 1967; Jednorowska, 1968; Bąk, 2004; Kaminski and Gradstein, 2005; Waśkowska, 2011a, b, 2015a), and species that occur in Carpathian deposits from the Early Eocene, i.e., Reticulophragmium amplectens (Grzybowski), Subbotina 

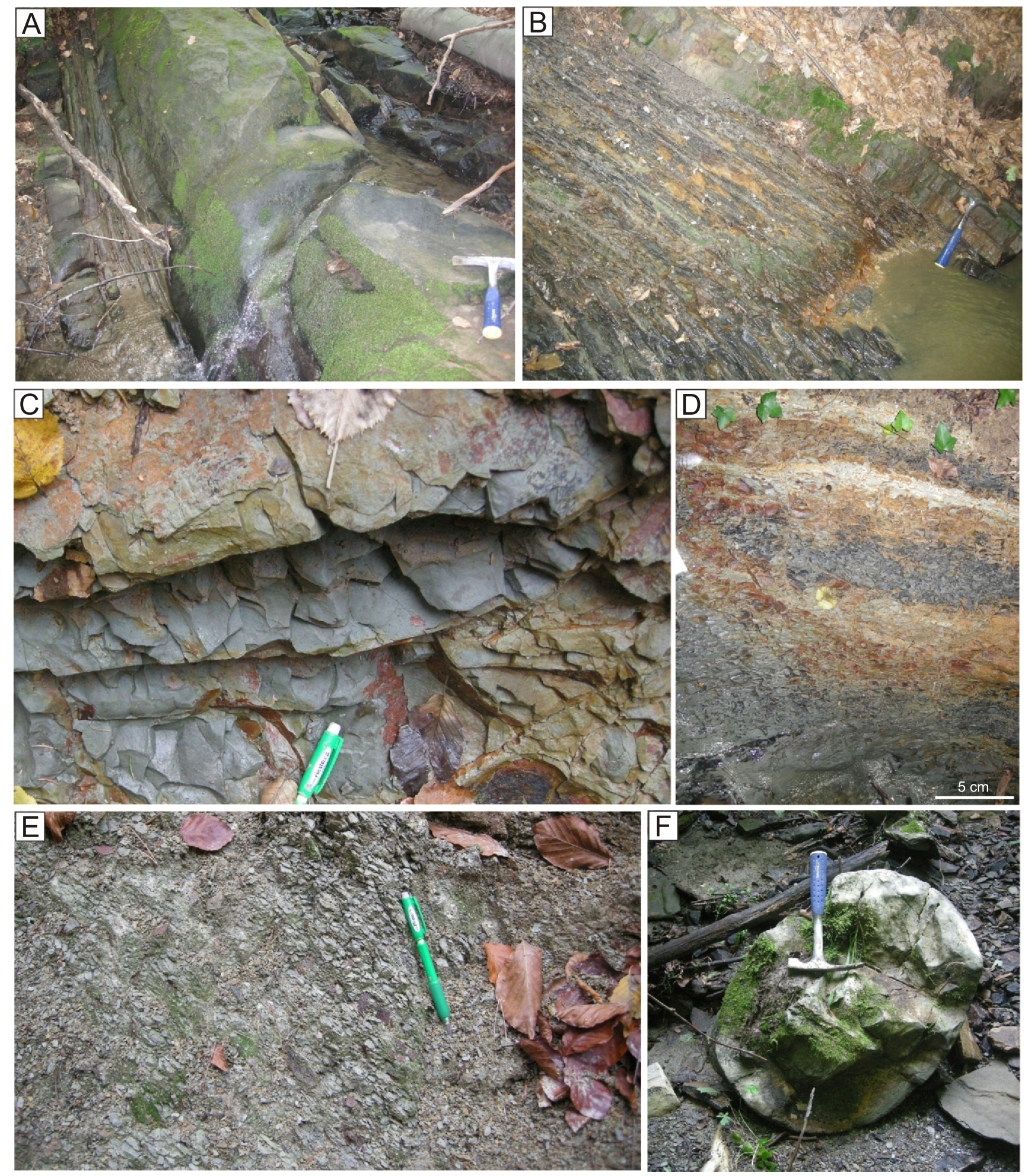

Fig. 8. Deposits of the Hieroglyphic Beds and Green Shales in the Lipie section

A - hieroglyphic-type deposits in uppermost part of the Ciężkowice Sandstones; B - thin-bedded flysch deposits of the Hieroglyphic Beds; C, E - deposits of the Green Shales; D - white bentonite layers within the Green Shales; F - calcareous concretions from chaotic deposits of the Green Shales 

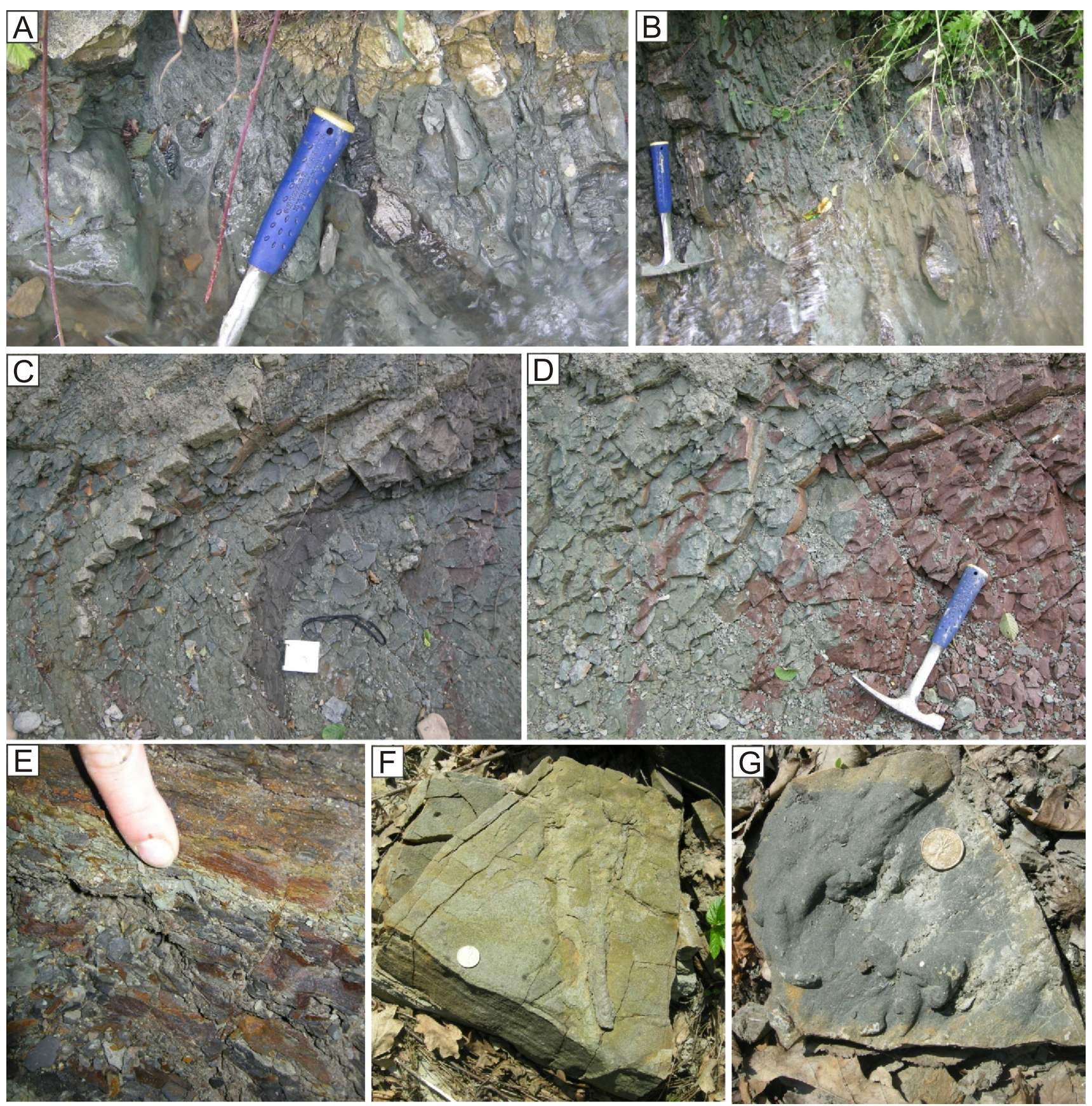

Fig. 9. The Hieroglyphic Beds in the Stradomka section

A - shales in lower part of section; B, C - thin-bedded deposits in middle part of section; D - variegated shales; $\mathbf{E}$ - bentonite layer within "the Black Eocene-type" deposits; F - bioglyphs; G - mechanoglyphs

hornibrooki (Brönnimann), Eratidus gerochi Kaminski et Gradstein, Haplophragmoides nauticus Kender, Kaminski et Jones and Pseudonodosinella elongata (Grzybowski) (e.g. Morgiel and Olszewska, 1981; Geroch and Koszarski, 1988; Olszewska et al., 1996; Olszewska, 1997; Kaminski and Gradstein, 2005; Cieszkowski et al., 2006b; Pearson et al., 2006; Waśkowska-Oliwa, 2008; Waśkowska, 2011a, b). The age of the assemblage is further supported by the superposition in the profile. Within the part of the profile with the cosmopolitan fauna, there is a distinct sequence of deposits containing crisis assemblages with numerous and small-sized Trochammina whose age was determined to be Early Eocene, based on planktonic and agglutinated foraminifera. Within the Lower Eocene variegated deposits, an increase in the number of Glomospira is observed (Waśkowska, 2015a).

The foraminiferal assemblages from the middle and upper parts of the thin-bedded flysch are characteristic of the Ammodiscus (Dolgenia) latus zone (Fig. 3) sensu Olszewska (1997), defining the Bartonian interval. The characteristic forms include Haplophragmoides parvulus Blaicher, Buzasina pacifica (Krasheninnikov), Ammomarginulina aubertae Gradstein et Kaminski, Eggerelloides propinqus (Brady), Insculptarenula aff. subvesicularis (Hanzlíková) and Bulbobaculites gorlicensis Waśkowska. In the upper part, 

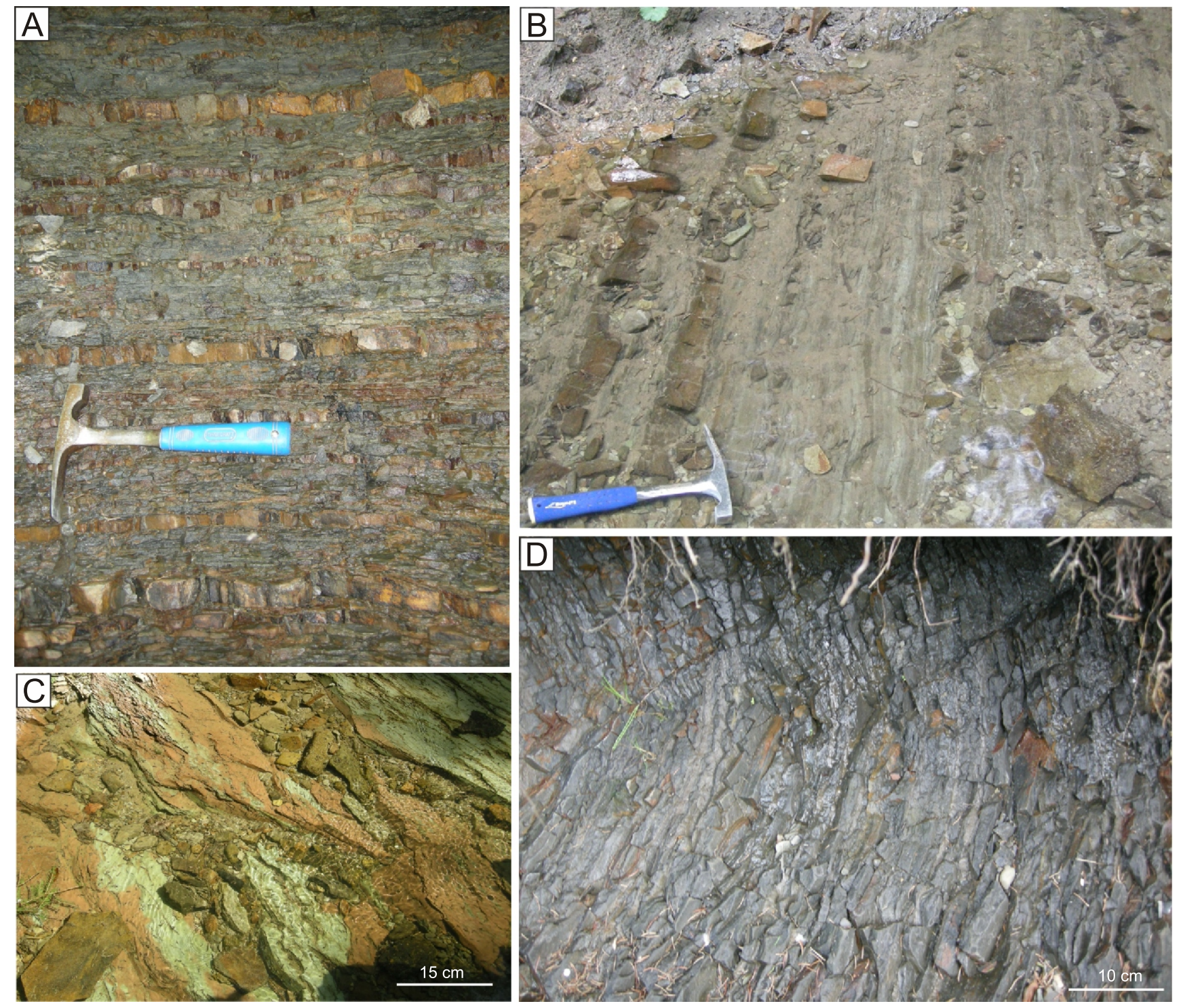

Fig. 10. Images of the Hieroglyphic Beds in the Olecka section

Thin-bedded flysch deposits: A - lower part of section, B - middle part of section, D - upper part of section; C - variegated shales

Spirosigmoilinella compressa Matsunaga appears (Waśkowska, 2015b; Fig. 5). In the lower part of "the Black Ecoene-type" complex, the assemblage contains calcareous foraminifera redeposited from Eocene deposits of shallower parts of the Silesian Basin. In the topmost part of the section, the assemblages are characteristic of the Priabonian Reticulophragmium rotundidorsatum (=gerochi) zone (Fig. 3) within which the index species occasionally occurs. In the near-top parts of the profile, the numbers of planktonic and calcareous benthic foraminifera, whose assemblages point to its Priabonian age, rise dramatically (Waśkowska, 2015b).

\section{BESKID ŚLASKI MTS. - ISTEBNA AREA}

Lithology. In this area, the Hieroglyphic Beds, with a thickness of up to ca. $130 \mathrm{~m}$, occur as thin-bedded shale-sandstone flysch (Fig. 3). In the bottom part, bioturbated shales of grey-green colouration are laminated with slightly darker grey shales (Fig. 6). Sandstone beds are minor constituents, with an average thickness of up to several centimetres. They are grey and laminated, with muscovite on their uppermost surfaces (Fig. 10). In the Kamesznica area, the lower part of the Hieroglyphic Beds is represented by grey and grey-green bioturbated shales with muscovite and spherosiderites. In the middle part of the section, there is a complex devoid of sandstones, ca. $25 \mathrm{~m}$ in thickness, composed of green soft shales. In the central part of the section, it contains variegated shales - green shales with red laminae (Figs. 3, 6 and 10). In this complex, intercalations were identified as small cream-coloured bentonites. The upper, shale-sandstone part of the profile contains complexes with more numerous thin sandstone beds, as well as complexes in which sandstones are rare. It is difficult to delineate the lower contact. The Hieroglyphic Beds are underlain by the Upper Istebna Shales and form thin-bedded flysch predominantly made up of dark grey sandy shales with muscovite. Spherosiderites are an accessory component of the profile, except for the part of the profile where sandstones are absent. The natural transition into the overlying deposits is gradual (Fig. 6). The proportions of grey-green shales typical of the Hieroglyphic Beds successively increase and abundant 
bioturbation also appears. The Hieroglyphic Beds successively grade into the Menilite Beds. Dark brown shales, characteristic of the Menilite Beds, appear in the profile: first as intercalations and then replacing the shales of the hieroglyphic-type. The quantity and thickness of sandstones also increase dynamically. The transition zone to the Menilite Beds is several metres thick.

Foraminiferal record and biostratigraphic age. The foraminiferal assemblages from the Hieroglyphic Beds are cosmopolitan (Fig. 3). In the lower part of the section, foraminifers are relatively abundant, whereas in the upper part of the profile, above the complex devoid of sandstones, the numbers drop rapidly. The Hieroglyphic Beds occur above the Upper Istebna Shales of Paleocene age, and the poorly taxonomically differentiated foraminifer assemblages contain a typical Paleogene species of Rzehakina fissistomata (Grzybowski) (Fig. 3). In the lower part of the Hieroglyphic Beds, there is a distinct increase in the number of Trochammina, and monospecific assemblages predominantly of dwarfed forms are found, denoting crisis-feature assemblages (Waśkowska, 2012, 2015a). In the lower part of the complex with the Trochammina assemblages, an increased proportion of Glomospira is observed, among which Glomospira charoides (Jones et Parker) predominates. In the assemblages of cosmopolitan and long-ranging species, Caudammina ovula (Grzybowski), Glomospira diffundens Cushman et Renz and Buzasina pacifica (Krasheninnikov) are sporadically found (Figs. 3 and 5). These species are most commonly found in the Senonian and Paleocene. Single occurrences of these species are also recorded in the Early Eocene. In turn, a typical Eocene species, also sporadically recorded in the lower part of the Hieroglyphic Beds is Eratidus gerochi Kaminski et Gradstein. Praesphaerammina subgaleata (Vasicek) is common. The foraminiferal assemblages from the middle Hieroglyphic shale complex with variegated shales have a slightly different character. They are characterised by increased taxonomic diversity, including the presence of Saccamminoides carpathicus Geroch, which has a relatively short stratigraphic range. This species occurs in the Carpathians exclusively in the Lower Eocene (e.g., Geroch, 1955, 1960; Geroch et al., 1967; Jurkiewicz, 1967; Morgiel and Szymakowska, 1978; Olszewska, 1980, 1981, 1997; Geroch and Nowak, 1984; Geroch and Koszarski, 1988; Rajchel, 1990; Waśkowska-Oliwa, 2000; Bąk, 2004; Olszewska et al., 2006; Waśkowska, 2011a,b), and allows establishing the age of this part of the profile.

In turn, the assemblages occurring within the thin-bedded shale-sandstone flysch above the shale complex with variegated deposits are taxonomically uniform. They contain only cosmopolitan, long-ranged forms typical for the Cretaceous and Paleogene. The most numerous group is comprised of the tubular forms Bathysiphon, Psammosiphonella and Rhabdammina, followed by Paratrochamminoides, Trochamminoides and Recurvoides, and then accompanying components like Ammodiscus, Ammosphaeroidina, Haplophragmoides, Glomospira, Karrerulina, Saccammina and Trochammina. There are very few species of biostratigraphic significance in this interval, so it cannot be subdivided into zones based on agglutinated foraminifera. Spirosigmoilinella compressa Matsunaga, found in one of the samples from the topmost part of the profile (Fig. 5), is known to range from the Middle/Late Eocene in the boreal seas (Charnock and Jones, 1990; Kaminski and Gradstein, 2005; Kaminski and Ortiz, 2014) and may suggest a Late Eocene age for this part of the profile. Similarly, poor assemblages were found in the lower part of the Menilite Beds. In this region, the lack of Globigerina Marls, which are an isochronic level in the Carpathians, poses difficulties in accu- rate marking of the upper contact of the Hieroglyphic Beds. The foraminiferal assemblages lack the planktonic forms which commonly occur in the near-top parts of the Hieroglyphic Beds in areas east of Istebna.

\section{DISCUSSION}

\section{LITHOLOGICAL DEVELOPMENT}

Lower boundary. The position of the base of the Hieroglyphic Beds depends on the development of the underlying lithostratigraphic units (Fig. 3). The Ciężkowice Sandstone is widely distributed in the Western Carpathians within the Silesian Nappe. It occurs as a series of large lenses predominantly made up of thick-bedded sandstones occurring within deposits with prevalent shales (Leszczyński, 1981). The Ciężkowice Sandstone forms the thickest and best-developed complex around its stratotype area (Leszczyński, 1981; Cieszkowski et al., 1991; Leszczyński and Radomski, 1994). At its maximum extent, the uppermost part reaches the Lutetian in the Reticulophragmium amplectens zone. Eastward and westward, a gradual reduction of the Ciężkowice Sandstone is observed. It is marked by the thinning of sandstone lenses, reduction in their number, as well as their greater fragmentation and dilution (Leszczyński, 1981). West of the Ciężkowice area, the relatively compact outcrops of the Ciężkowice Sandstone lose their continuity. This phenomenon is recorded from as far as Mszana Dolna and Sucha Beskidzka (e.g., Książkiewicz 1974a, b; Burtan, 1978) and continues up to the areas of Istebna (Burtanówna et al., 1937; Burtan et al., 1956; Burtan, 1972, 1973, 1978) and Moravia (e.g., Menčík and Tyráček, 1985; Ryłko, 2004; Bubik, 2007). Additionally, the stratigraphic range of the Ciężkowice Sandstone on the peripheries of its distribution is successively shorter; its uppermost part is dated as Early Eocene or it descends to the Paleocene/Eocene boundary. The contact zone with the Hieroglyphic Beds is clearly marked in the profiles (Figs. 3 and 6). The transitional complexes, which constitute a gradual transition between the Ciężkowice Sandstone and the Hieroglyphic Beds, are relatively thin with the thickness of up to several metres. They are characterised by the presence of grey or grey-green shales of the Hieroglyphic type, along with dark shales typical for the Ciężkowice Sandstones. They are interbedded by grey and beige sandstones whose layers thin up the section of the complex, whilst simultaneously the frequency of their occurrence decreases. It can be assumed that the sedimentation of the Ciężkowice Sandstone terminated with the last compact complex of thick-bedded sandstones with a characteristic beige colouration.

The Hieroglyphic Beds occur above the Ciężkowice Sandstone, and in case of its absence - directly above the Istebna Beds. Such a situation takes place in the western part of the study area (Figs. 3 and 6), and it continues in the Czech part of the Outer Carpathians (Eliáš, 2001; Bubik, 2007). The uppermost part of the Istebna Beds (Upper Istebna Shales) is represented by thin-bedded flysch predominantly composed of dark shales. The sedimentary transition from the Upper Istebna Shales into the Hieroglyphic Beds is gradual (Burtan, 1936; Burtanówna et al., 1937; Geroch, 1960; Fig. 6), and the contact between them is conventionally marked in the profile where the grey or/and grey-greenish shales typical of Hieroglyphic Beds prevail over the dark grey Istebna Shales with muscovite. Shales of the Hieroglyphic Beds contain abundant bioturbation that can be used as an additional criterion for marking the 
boundary. In many places, at the contact between the Hieroglyphic Beds and the underlying divisions, variegated shales appear (e.g., Burtan et al., 1956; Burtan, 1972, 1973; Szymakowska, 1979; Leszczyński, 1981; Wójcik et al., 1993a, b; Leszczyński and Radomski, 1994) although they are not always present (Figs. 3 and 6).

Upper boundary. The Hieroglyphic Beds contact with the Globigerina Marls, and, if the latter are absent, directly with the Menilite Beds (Figs. 3 and 7). The Globigerina Marls occur widely in the Outer Carpathians and their sedimentation lasted a short period from the latest Eocene to the Oligocene (e.g., Blaicher, 1970; Olszewska, 1983, 1984; Leszczyński, 1997). Their thickness within the Silesian Nappe is estimated at several metres (e.g., Geroch et al., 1967; Leszczyński, 1996, 1997). The Globigerina Marls are a complex of pelagic carbonates characterised by the presence of marly limestones and cream-coloured marls with a rich planktonic foraminiferal fauna, interbedded by grey and light green marls and marly shales (Geroch et al., 1967; Blaicher, 1970; Olszewska, 1983, 1984; Leszczyński, 1996, 1997). The transition zone between the Hieroglyphic Beds and the overlying unit is relatively thin, up to $1 \mathrm{~m}$. In the uppermost part of the Hieroglyphic Beds, the carbonate content increases dramatically, and Menilite-type shales occur as interbeds (Fig. 7). Leszczyński (1996) marked this contact on the first green marly shale underlying a light-coloured marl that is the discriminating feature of the Globigerina Marls.

Locally, the Globigerina Marls do not form a separate complex but constitute intercalations within dark brown shales characteristic of the Menilite Beds - components of thin-bedded flysch. Authigenic structural material of the Globigerina Marls was diluted by terrigenous material. Such a situation occurs, e.g., in the Gorlice area (Szymakowska, 1979; Figs. 3 and 7), as well as in the Grybów, Bochnia, Limanowa, Wieliczka, Myślenice, Lachowice, Sucha-Beskidzka, Bielsko-Biała and Istebna sections (e.g., Burtan, 1936, 1964a, 1973; Burtanówna et al., 1937; Nowak, 1963, 1964; Sikora, 1963; Burtan and Skoczylas-Ciszewska, 1964a, b; Szymakowska, 1964; Paul, 1993). In these areas, the separation of the Globigerina Marls from the Menilite Beds is not possible. The contact between the Hieroglyphic Beds and Menilite Beds is then transitional.

Lithology. The Hieroglyphic Beds in the Silesian Nappe are an informal lithological unit. The name was transferred from the area of the Skole Nappe where the Eocene deposits of thin-bedded flysch were called "hieroglyphic" because of significant concentration of trace fossils on the surfaces of sandstone beds (Paul and Tietze, 1879). In principle, since the 1930s the term "Hieroglyphic Beds" has appeared regularly in reference to the deposits of the Silesian Nappe, characterising the shale-sandstone deposits of Eocene age (e.g., Grzybowski, 1921; Ksiażkiewicz, 1932; Burtanówna, 1933; Burtanówna et al., 1937; Guzik and Pożaryski, 1949; Książkiewicz, 1951, 1974b; Burtan, 1954, 1964a, b, 1972, 1973, 1974, 1978; Skoczylas-Ciszewska, 1954; Burtan et al., 1956; Jurkiewicz, 1959, 1967; Ślączka, 1959; Geroch, 1960; Bieda et al., 1963, Burtan and Skoczylas-Ciszewska, 1964a, b, c; Burtan and Szymakowska, 1964; Koszarski and Kuciński, 1965; Koszarski, 1966; Koszarski and Żytko, 1966; Jurkiewicz, 1967; Geroch et al., 1967; Książkiewicz, 1974a, b; Szymakowska and Wójcik, 1981,1992; Geroch and Koszarski, 1988; Cieszkowski et al., 1991, 2006a; Paul, 1991, 1993; Wdowiarz et al., 1991; Cieszkowski, 1992; Wójcik et al., 1993a, b; Wójcik and Rączkowski, 1994; Leszczyński and Radomski, 1994; Paul et al., 1996; Ryłko, 2004; Chodyń and Waśkowska-Oliwa, 2006; Golonka and Waśkowska-Oliwa, 2007; Waśkowska et al., 2008; Waśkowska, 2012, 2014a, b, c, Golonka et al., 2013;
Waśkowska and Cieszkowski, 2014, Kopciowski et al., 2014). In the Czech Republic, deposits corresponding to the Hieroglyphic Beds were described and distinguished as the Roznov beds. They are defined as deposits occurring between the Istebna and Menilite Beds (Menčík and Tyráček, 1985; Eliáš, 2001; Picha et al., 2006; Bubik, 2007).

Lithological heterogeneity within the Eocene deposits defined as the Hieroglyphic Beds sensu lato is very obvious (Figs. 3, 6 and 7). It pertains primarily to the thickness and frequency of sandstone beds in profiles. Grey quartzose sandstones with silica cement predominate. Greenish sandstones with glauconite are also widespread. The zones of predominant dark shales are characterized by the appearance of brown sandstones with abundant muscovite. As a rule, these are very fine- or fine-grained sandstones grading upwards into shales (Figs. 7-9). They occur as single very thin or thin beds, with the thickness fluctuating from 1 to $5 \mathrm{~cm}$, although there are some sections with medium-thick beds. The sandstones are laminated and massive. The beds commonly show parallel and wavy lamination, more rarely - cross-lamination. The number of sandstone beds in the profiles is very variable, and most of the units are predominantly made up of shales. The sand/shale ratio in the thin-bedded flysch complexes varies from about 10 to ca. $30 \%$. Sandstones occur within the complexes of grey-green, non-calcareous laminated shales with variable proportions of individual colour variants. The presence of abundant bioturbation is a characteristic feature of these shales (Fig. 9).

Thick, lithologically relatively uniform, sandstone-free (or with minor quantities of thin-bedded sandstones) complexes known as the Green Shales are distinguished above the Hieroglyphic Beds either as a separate informal lithostratigraphic unit, or as a main component of the Hieroglyphic deposits. The Green Shales function as a lithostratigraphic unit chiefly in the eastern sector of the Polish Outer Carpathians, marked in cartographic works from the areas of Męcina, Rożnów Lake, Ciężkowice, Rzepiennik, Jasło and Pilzno (Burtan and Skoczylas-Ciszewska, 1964a; Koszarski et al., 1964; Kuciński, 1965; Koszarski, 1966; Koszarski and Żytko, 1966; Cieszkowski et al., 1991; Cieszkowski, 1992; Wójcik et al., 1993a, b; Leszczyński and Radomski, 1994; Waśkowska, 2014b). In the Gorlice area, the Green Shales have not been found to date (Szymakowska, 1979), although the sandstone-free complex composed of uniform Green Shales overlying the thin-bedded flysch could be cartographically distinguishable (Fig. 3). The shale-type development of deposits between the Ciężkowice Sandstone and the Menilite Beds was pointed out by Świdziński (1973). However, detailed observations indicate that thick complexes of grey-green shales occur at various stratigraphic positions; an example is the Szczyrzyc Foothills, where $70 \mathrm{~m}$ of the profile above the topmost part of the Ciężkowice Sandstone is composed of grey-green shales resembling Green Shales (Waśkowska, 2014a, c, 2015b; Figs. 3, 6 and 9). In the Beskid Śląski Mountains (Jasnowice area), a $25 \mathrm{~m}$ thick sandstones-free complex dominated by grey-green shales occupies the middle part of the Hieroglyphic Beds (Figs. 3, 6 and 10). In turn, in the Istebna area, the lower part of the Hieroglyphic Beds is almost sandstone-free (Waśkowska, 2015a). Wójcik et al. (1993b) noted sandstone-free green shale complexes from the lower part of the Hieroglyphic Beds in the Jasło area.

Other shale units are also in use as regards Eocene deposits corresponding to the Hieroglyphic Beds. A note on the shale nature of the complex between the Ciężkowice Sandstone and Menilite Beds was made by Świdziński (1950) who distinguished variegated shales in the Grybów area, describing them as "claystone shales or shale clays, greenish, interbedded by 
characteristic brown-purple shales". At present, the term "variegated shales" is traditionally applied in the Polish geological nomenclature to sandstone-free deposits containing red shales as its most characteristic component. In the mid-twentieth century, this term regarded the prevalence of variously coloured laminated shales, although red shales were not a necessary component. Therefore, in many cartographic divisions of that time, the variegated shales were separated in place of the Hieroglyphic Beds (developed as thin-bedded flysch) or as a variant name (e.g., Nowak, 1963; Sikora, 1963; Żytko, 1963; Burtan, 1964b, c; Burtan and Skoczylas-Ciszewska, 1964a, b, c; Skoczylas-Ciszewska, 1964), suggesting the presence of laminated, sandstone-free or nearly sandstone-free complexes. These deposits most often occur above the Ciężkowice Sandstone or Istebna Beds where they form a characteristic "layer cake" of lighter grey and/or green shales with darker ones. A large quantity of dark shales causes them to be very similar macroscopically to the shales of the Istebna Beds, especially because the latter complexes contain spherosiderites, like the Istebna Beds (Książkiewicz, 1974b; Burtan, 1978; Wójcik and Rączkowski, 1994; Waśkowska, 2015a). Locally, the Hieroglyphic Beds include complexes with a major proportion of sandstones, or made up predominantly of sandstones. Książkiewicz (1974b) reported that the sandstone/shale ratio in the lower part of the Hieroglyphic Beds might be 1:1. East of Gorlice, a 50-75 m thick complex containing thick-bedded sandstones with intercalations of green-grey and dark grey shales was reported in the topmost part of the Hieroglyphic Beds. In their upper part, there are calcareous shales, above which the Globigerina Marls are developed (Wdowiarz et al., 1991). In turn, in the Wojnicz area, thick-bedded sandstone occurs within the Middle Eocene Hieroglyphic Beds (Koszarski and Kuciński, 1965).

The lithological development depends on the configuration of the sedimentation system, including the distribution and activity of source areas, as well as on the dynamics of gravitational processes and morphological conditions. Thus, the alternative occurrence of thin-bedded shale-sandstone, and sandstone-free deposits is a natural consequence of the geometry of the sedimentation cone. However, the analysis of data from reference sources pertaining to the Hieroglyphic Beds indicates that sandstone-shale deposits are replaced by shale deposits, a phenomenon which is widespread in the eastern region of the study area and provides the basis for subdividing a lithostratigraphic unit now informally called the Green Shales. After formalisation, this division should operate at the rank of member, whereas the Hieroglyphic Beds should be a superior unit.

The variable sedimentation regime determines the lithological types. In the inventory of the Hieroglyphic Beds, besides the typical deposits of grey-green shales and thin-bedded sandstones, the majority of which are turbidites, there are deposits testifying to the considerable effect of hemipelagic sedimentation. The most significant among them are the green shales that constitute a widely distributed facies in the Silesian Basin, and testify to a regional-scale reduction in terrigenous material supply. The complexes with red and dark shales, and complexes with bentonites should also be listed among other Hieroglyphic deposits developed under conditions of the quiet sedimentation regime.

The complexes with red shales are customarily termed "variegated shales". Their characteristic property is the occurrence of red or cherry soft shales with intercalations of green-grey shales (Figs. 4, 9 and 10). In the Hieroglyphic Beds, the red shales are predominantly clayey deposits, made of finer material than the typical grey-green shales (Waśkowska, 2015a).
They occur in different lithostratigraphic positions within the $\mathrm{Hi}-$ eroglyphic Beds (e.g., Burtanówna et al., 1937; Książkiewicz, 1974b; Burtan, 1978; Paul, 1993; Wójcik et al., 1993b; Leszczyński and Radomski, 1994; Wójcik and Rączkowski, 1994; Waśkowska, 2014c, 2015a) and mostly do not show lateral continuity in the western part of the Outer Carpathians except for the variegated deposits underlying the Hieroglyphic Beds and overlying the Ciężkowice Sandstone (e.g., Burtan et al., 1956; Burtan, 1972, 1973; Szymakowska, 1979; Leszczyński, 1981; Wójcik et al., 1993a, b; Leszczyński and Radomski, 1994). The variegated deposits within the Hieroglyphic Beds usually occur as thick shale complexes (Figs. 3 and 6). As a rule, they are surrounded by grey-green shales, whereas sandstones in these zones are rare or disappear. In the Hieroglyphic Beds, variegated shale complexes have thicknesses from several to several tens of metres. In the Brzesko and Bochnia region, they are markedly thicker, and variegated deposits replace the thin-bedded flysch typical for the Hieroglyphic Beds (Skoczylas-Ciszewska, 1952, 1954) or constitutes a thick shale complex occurring beneath the Menilite Beds (Skoczylas-Ciszewska and Burtan, 1954). In the Jasło area (eastern region), the variegated deposits are a permanent component characteristic of the Hieroglyphic Beds. They constitute intercalations within the thin-bedded flysch or they are a predominant component. In the latter case, thin-bedded sandstones are relatively rare (Szymakowska and Wójcik, 1981, 1992). The variegated Eocene shales have the nature of oceanic red beds containing deep-water agglutinated foraminiferal assemblages. They are very widespread not only in the Silesian Basin, but are known as well from other Carpathian basins which developed from the Protosilesian Basin.They are also developed on a large scale in the neighbouring Magura Basin where they are formally distinguished as the Łabowa Shale Formation.

The Middle Eocene complexes of Hieroglyphic Beds contain concentrations of bentonites (Fig. 3). They form thin layers usually with a thickness of about several millimetres, with white, cream or pinkish colouration (Chodyń and Waśkowska-Oliwa, 2006; Waśkowska-Oliwa et al., 2008; Waśkowska, 2014b). The preservation of fine pyroclastic material in deep-sea conditions, supplied to the basin first by air, then successively transported in a column of water, is possible only under conditions of calm sedimentation. It is a sign of episodes of lower sedimentation rates together with a diminished supply of terrigenous material. Bentonites occur within the sandstone-free or nearly sandstone-free deposits developed as grey-green shales laminated with darker grey ones (Fig. 3). Alternatively, they also occur within shales dominated by dark deposits, showing similarities with "the Black Eocene-type" deposits known from the areas where there are units of the Fore-Magura group (e.g., Burtan, 1978; Olszewska, 1981; Cieszkowski et al., 1985; Połtowicz, 1985; Cieszkowski, 1986; Paul and Ryłko, 1987; Oszczypko and Wójcik, 1993). They are also recorded in areas of variegated shale deposits. The bentonite-bearing deposits occur in the lower and middle parts of the Hieroglyphic Beds. They are found in Lower Eocene deposits of the Kamesznica area, and in Middle Eocene deposits of the Szczyrzyc Depression. The Early Eocene bentonites correspond lithologically to the Glichów horizon in the Subsilesian Nappe (Cieszkowski et al., 2006b; Waśkowska, 2011a), and have a stratigraphic position similar to the bentonites known from variegated deposits of the Magura Nappe (Cieszkowski et al., 2011), although the stratigraphic and geochemical similarities were not confirmed by detailed analyses.

The lithological component that accompanies nearly sandstone-free zones is sideritic concretions (Fig. 3). They occur ex- 
clusively in grey shales or grey shales laminated with darker ones. The siderites are loaf shaped, usually with diameters of several tens of centimetres, or stretched out flattened concretions, thinning or pinching out laterally at a scale of 3-4 m. They are composed of dark grey sideritic pelite and their surfaces are covered by limonitic substances.

The sandstone-free complexes are associated with the occurrence of subaqueous slumps (Fig. 3). These were recorded near the Rożnów Lake, in the Szczyrzyc Foothills (e.g., Cieszkowski, 1992; Cieszkowski and Waśkowska, 2013a, b, 2014; Waśkowska, 2014b) and in the Gorlice region. The dimensions of these slumps vary from several metres to several hundred metres, and depend on the amount of material shifted. Their development is also heterogeneous. In the Gorlice area, the clasts of redeposited material are represented exclusively by grey shales. The samples collected in the nearby area contain - apart from the autochthonous fauna - forms redeposited from Cretaceous variegated deposits. In the Szczyrzyc Foothills, the slump mass contains sandstone and shale clasts reminiscent of deposits of the Istebna Beds (Waśkowska, 2015b). The olistostrome outcropping in the Rożnów Lake area is tripartite and contains diverse Eocene-Late Cretaceous deposits (Waśkowska and Cieszkowski, 2014). The submarine gravitational mass-movement deposits are found in the middle part of the Hieroglyphic Beds. The micropalaeontological data indicate that the shifts took place in the Middle Eocene and point to increased geotectonic activity at that time.

The Hieroglyphic Beds sensu lato developed chiefly after the main deposition phases of a great sedimentation cycle marked by the intensive deposition of coarse-grained clastics in the Silesian Basin, from the Late Cretaceous through the Early Eocene. The complexes corresponding lithologically to the Hieroglyphic deposits also occur within the Ciężkowice Sandstone, and have been distinguished there as a facies associated with the Hieroglyphic Beds that feature turbidite characteristics (Leszczyński, 1981). They occur chiefly in the surroundings of thick-bedded Ciężkowice Sandstones. They differ from the typical Hieroglyphic Beds by the increased proportion of sandstones, and by the occurrence of dark grey shales and white sandstones. These sandstones feature Ciężkowice-type characteristics, and they have the same palaeotransport directions, whereas grey hieroglyphic sandstones with glauconite were probably supplied from other source areas (Leszczyński, 1981).

\section{FORAMINIFERAL RECORD}

Majority of agglutinated foraminifera living in deep flysch basins are long-ranged forms, and therefore have limited use in stratigraphic dating. In these habitats, the evolutionary mechanisms, depending on environmental stimuli prompting taxonomical differentiation, proceed slowly. Therefore, the dating of deposits based on deep-water agglutinated forms is not very precise (Waśkowska-Oliwa, 2007; Waśkowska, 2011b). The foraminiferal assemblages from the Hieroglyphic Beds show little taxonomical diversity (Figs. 11-13), therefore age dating based on this group of fossils brings about certain diagnostic difficulties. Planktonic and benthic calcareous foraminifera are occasional components of the assemblages whereas those occurring in the lower parts of the Hieroglyphic Beds are usually redeposited. They occur en mass in the topmost part of the Hieroglyphic Beds/Green Shales, as well as in the overlying Globigerina Marls.

The Hieroglyphic Beds are characterised by a differentiated foraminiferal record, although foraminifer tests are a common component of shales, indicating that the foraminiferal associations were permanently developing during the sedimentation of these deposits. The stratigraphic range of the Hieroglyphic Beds is variable; their upper boundary is almost isochronous whereas the lower boundary depends on the development of the Ciężkowice Sandstone (Fig. 3). Thus, the lower boundary of the Hieroglyphic Beds in the regions of maximum thickness of the Ciężkowice Sandstone lenses (e.g., the Rożnów Lake and Ciężkowice areas) occurs within the Lutetian, while towards the west, it successively descends to the Early Eocene, or to the Paleocene/Eocene boundary.

Ypresian assemblages. Analyses of the sections and published data indicate that the lower part of the Hieroglyphic Beds usually contains undiagnostic assemblages of agglutinated foraminifera, predominantly comprised of cosmopolitan forms known from the Cretaceous and Paleogene from many different regions of the world. The unification of Ypresian and Lutetian foraminiferal assemblages in the Hieroglyphic Beds is a common phenomenon, but the lack of index forms makes biostratigraphic determinations difficult. Data from publications pertaining to the fauna of this part of the Hieroglyphic Beds are scarce, and their little usefulness for biostratigraphy has been emphasised (Książkiewicz, 1974b). In lithostratigraphic studies, chiefly the diagnostic microfauna is cited from only upper parts of the profile (e.g., Książkiewicz, 1974b; Szymakowska, 1979; Cieszkowski, 1992; Leszczyński and Radomski, 1994).

In integrated biostratigraphical subdivisions of the Early Eocene in the Outer Carpathians, the assemblages with numerous Glomospira, followed by those with Saccamminoides carpathicus Geroch, are of diagnostic significance (e.g., Morgiel and Olszewska, 1981; Olszewska et al., 1996; Olszewska, 1997). In the material analysed, increased quantity of Glomospira from the Lower Eocene interval was found only in the Istebna region (Fig. 3). In the Szczyrzyc section, this lithostratigraphic interval contains assemblages with undiagnostic fauna, and the amount of Glomospira increases dynamically only in the variegated shales (Waśkowska, 2015a). In the Silesian Nappe, Glomospira Acme assemblages are relatively common, occurring widely in the variegated complexes separating the Ciężkowice Sandstones (e.g., Jurkiewicz, 1959, 1967; Geroch, 1960; Cieszkowski, 1992). There is no palaeontological data on this type of fauna from the regions where the Ciężkowice Sandstones are absent, i.e., where the Hieroglyphic Beds are in direct contact with the Istebna Beds. The presence of species Saccamminoides carpathicus Geroch in the assemblages is very sporadic, except for samples obtained from variegated shales where specimens of this species are common (several specimens per sample). On the Czech side, the Roznov Beds (Eliáš, 2001; Golonka and Waśkowska-Oliwa, 2007), which are lateral equivalents to the Hieroglyphic Beds, descend to the Paleocene (Bubik, 2007).

Within the Early Eocene assemblages, there is a marked increase in the proportions of Trochammina (Figs. 3 and 13) that is considered a cosmopolitan form and occurs universally in the foraminiferal assemblages of flysch basins of the Outer Carpathians, but it is normally an accessory component. In the Early Eocene, the quantity of Trochammina in the Hieroglyphic Beds increased dramatically to several tens of percent, sometimes constituting the majority of the assemblage (Waśkowska, 2012, 2015a). The characteristic feature of the assemblages with numerous Trochammina is, on the one hand, the increased number of foraminifera, and - on the other hand - the occurrence of dwarfed individuals. Such assemblages were identified in the Gorlice, Szczyrzyc and Istebna areas (Fig. 3). Their Ypresian age was determined based on agglutinated and planktonic foraminifera (Waśkowska, 2012, 2015a). In the 


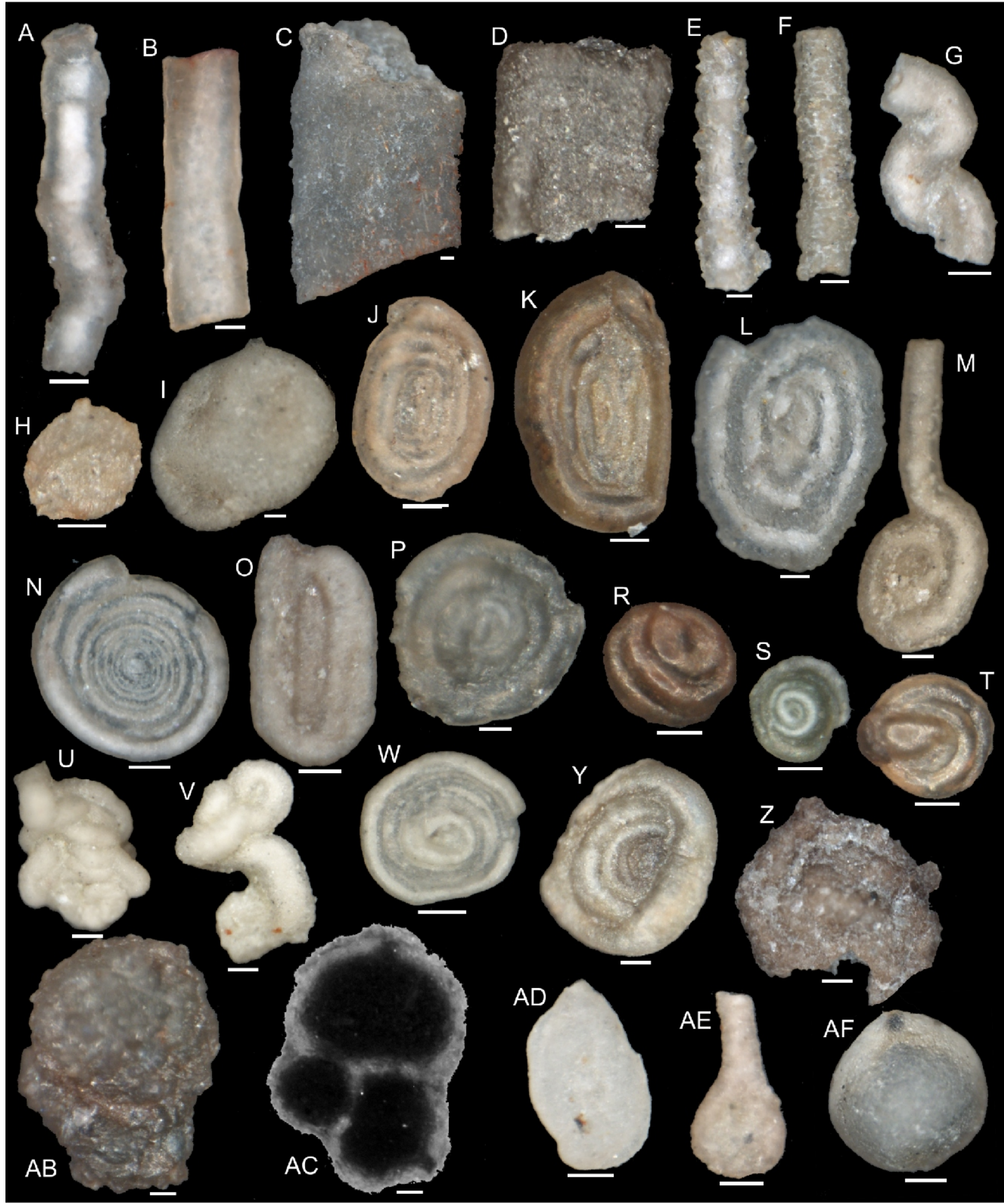

Fig. 11. Foraminifera from the Hieroglyphic Beds of the Silesian Nappe

A - Bathysiphon sp. (sample Gorlice 22/6/13); B - Bathysiphon sp. (Gorlice 23/8/13); C - Nothia sp./Bathysiphon sp. (Gorlice 22/6/13); D Nothia sp./Bathysiphon sp. (Olecka 134/20/09); E - Psammosiphonella cylindrica (Glaessner) (Gorlice 23/8/13); F - Psammosiphonella discreta (Brady) (Gorlice 23/8/13); G - Rhizammina sp. (Gorlice 23/8/13); H - Saccammina grzybowskii (Schubert) (Olecka 132/17/19); I Placentammina placenta (Grzybowski) (Gorlice 18/26/13); J - Ammodiscus peruvianus Berry (Gorlice 19/15/12); K - Ammodiscus peruvianus Berry (Gorlice 27/7/12); L - Ammodiscus (Dolgenia) latus Grzybowski (Gorlice 27/7/12); M - Ammodiscus (Dolgenia) latus Grzybowski (Gorlice 17/4/12); N - Ammodiscus cretaceus (Reuss) (Gorlice 27/7/12); O - Glomospira serpens (Grzybowski) (Gorlice 17/4/12); P - Glomospira diffundens Cushman et Renz (Olecka 51/6/09); R - Glomospira charoides (Jones et Parker) (Olecka 108/25/09); S - Glomospira charoides (Jones et Parker) (Gorlice 19/15/12); T - Glomospira charoides (Jones et Parker) (Olecka 108/25/09); U Glomospira glomerata (Grzybowski) (Gorlice 19/15/12); V - Glomospira glomerata (Grzybowski) (Gorlice 19/15/12); W - Glomospira gordialis (Jones et Parker) (Gorlice 19/15/12); Y - Dolgenia sp. (Olecka 108/25/09); Z - Thurammina sp. (Gorlice 22/6/13); AB Saccamminoides carpathicus Geroch (Olecka 116/41/06); AC - Saccamminoides carpathicus Geroch (Oecka 137/23/09); AD Spirosigmoilinella compressa Matsunaga (Gorlice 27/7/12); AE - Caudammina excelsa (Dylążanka) (Gorlice 15/2/12); AF - Caudammina ovula (Grzybowski) (Olecka 133/18/09); scale bar $100 \mu \mathrm{m}$ 


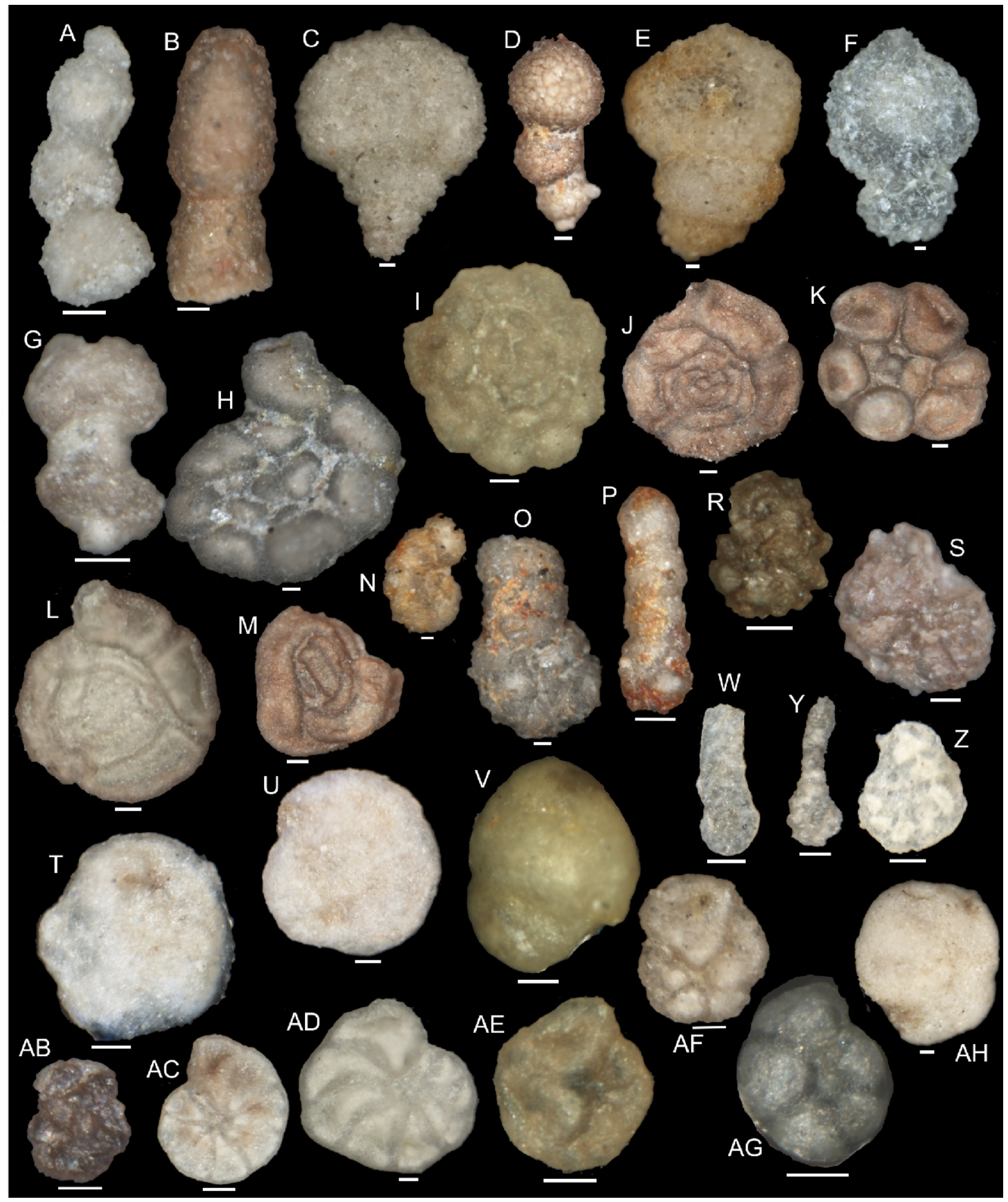

Fig. 12. Foraminifera from the Hieroglyphic Beds of the Silesian Nappe

A - Subrepohax scalaris (Grzybowski) (sample Gorlice 17/4/12); B - Pseudonodosinella elongata (Grzybowski) (Gorlice 27/7/12); C Reophax pilulifer Brady (Gorlice 19/15/12); D - Reophax sp. (Gorlice 18/26/13); E - Reophax pilulifer Brady (Gorlice 19/15/12); F - Reophax duplex Grzybowski (Gorlice 18/5/12); G - Reophanus berrgreni Gradstein et Kaminski (Gorlice 27/7/12); H - Paratrochamminoides deflexiformis (Noth) (Gorlice 27/7/12); I - Trochamminoides proteus (Karrer) (Lipie 79/13/09); J - Trochamminoides cf. dubius (Grzybowski) (Olecka 108/25/09); K - Trochamminoides subcoronatus (Grzybowski) (Olecka 108/25/09); L - Trochamminoides cf. dubius (Grzybowski) (Lipie 19/15/12); M - Paratrochamminoides sp. (Olecka 108/25/09); N - Ammobaculites sp. (Gorlice 14/1/12); O - Ammobaculites sp. (Stradomka 29/45/06); P - Ammobaculites agglutinans d'Orbigny (Olecka 132/17/09); R - Ammomarginulina aubertae Gradstein et Kaminski (Lipie 85/19/09); S - Ammomarginulina aubertae Gradstein et Kaminski (Stradomka 1/str/03); T - Buzasina pacifica (Krasheninnikov) (Stradomka 69/53/05); U - Buzasina pacifica (Krasheninnikov) (Stradomka 69/53/05); V - Buzasina pacifica (Krasheninnikov) (Lipie 81/15/09); W - Eratidus gerochi Kaminski et Gradstein (Olecka 134/20/09); Y - Eratidus gerochi Kaminski et Gradstein (Gorlice 14/22/13); Z Eratidus gerochi Kaminski et Gradstein (Gorlice 17/4/12); AB - Haplophragmoides porrectus Maslakova (Olecka 116/41/09); AC Haplophragmoides walteri (Grzybowski) (Gorlice 19/15/12); AD - Haplophragmoides cf. walteri (Grzybowski) (Gorlice 19/15/12); AE Haplophragmoides sp. (Lipie 86/20/09); AF - Haplophragmoides kirki Wikenden (Gorlice 17/4/12); AG - Haplophragmoides eggeri Cushman (Stradomka 25/44/06); AH - Praesphaerammina subgaleata (Vasicek) (Gorlice 14/22/13); scale bar $100 \mu \mathrm{m}$ 


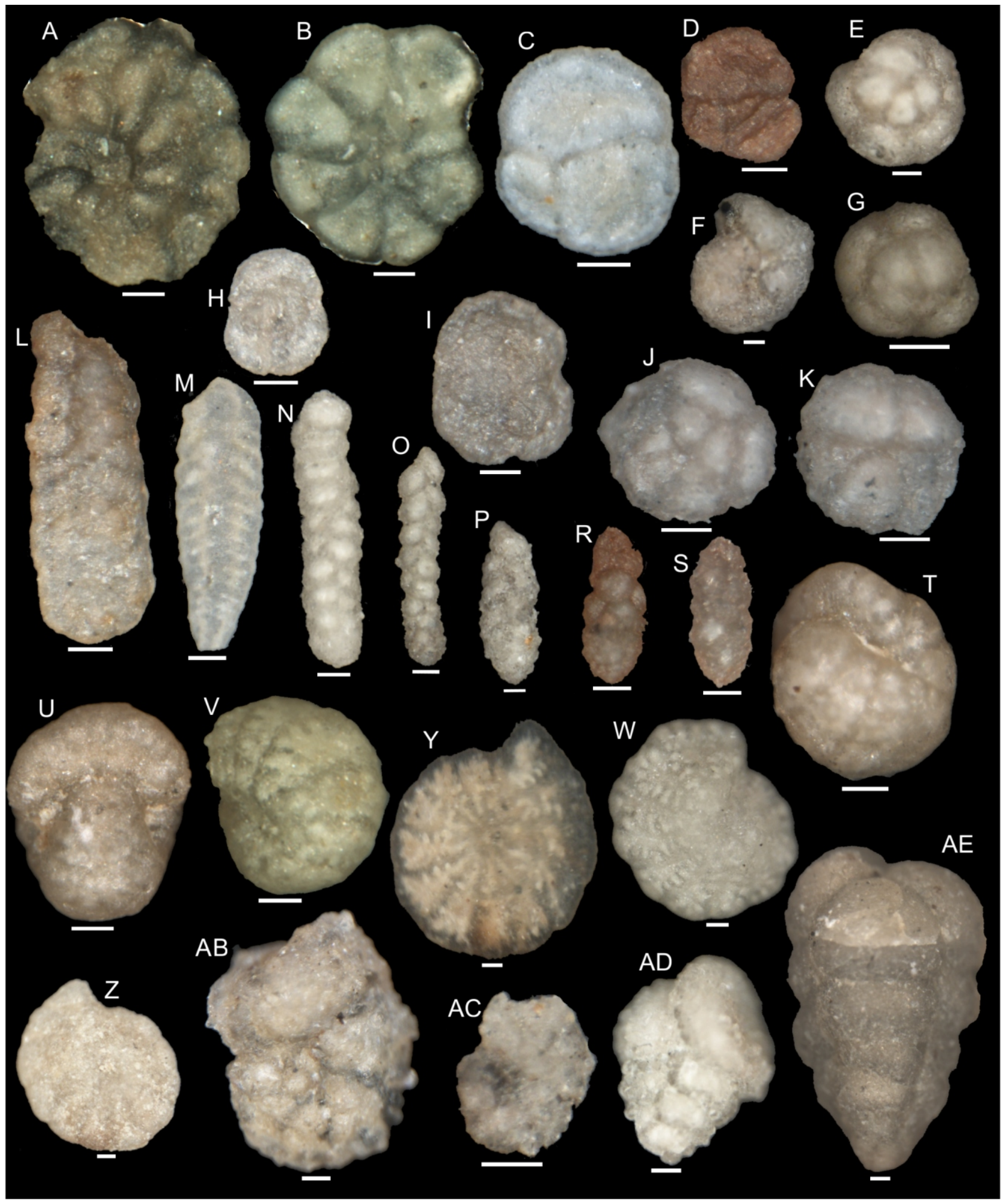

Fig. 13. Foraminifera from the Hieroglyphic Beds of the Silesian Nappe

A - Haplophragmoides excavatus Cushman (sample Lipie 82/15/09); B - Haplophragmoides nauticus Kender, Kaminski et Jones (Lipie 82/15/09); C - Ammosphaeroidina pseudopauciloculata (Mjatliuk) (Gorlice 18/5/12); D - Ammosphaeroidina pseudopauciloculata (Mjatliuk) (Olecka 108/25/09); E - Thalmannammina subturbinata (Grzybowski) (Gorlice 19/15/12); F - Recurvoides anormis Mjatliuk (Gorlice 10/18/13); G - Thalmannammina subturbinata (Grzybowski) (Lipie 86/20/09); H - Trochammina sp. (Olecka 133/18/09); I -Trochammina sp. (Olecka 133/18/09); J - Insculptarenula aff. subvesicularis (Hanzlíková) - central side (Stradomka 1/str/03); K - Insculptarenula aff. subvesicularis (Hanzlíková) - dorsal side (Stradomka 1/str/03); L -Spiroplectammina spectabilis (Grzybowski) (Olecka 132/17/09); M Spiroplectammina spectabilis (Grzybowski) (Gorlice 10/18/13); N - Karrerulina conversa (Grzybowski) (Gorlice 19/15/12); O - Karrerulina conversa (Grzybowski)(Gorlice 19/15/12); P - Karrerulina horrida (Mjatliuk) (Gorlice 19/15/12); R - Karrerulina sp. (Olecka 108/25/09); S Karrerulina coniformis (Grzybowski) (Olecka 108/25/09); T - Reticulophragmium gerochi Neagu et al. (Stradomka 64/58/05); U Reticulophragmium gerochi Neagu et al. (Stradomka 64/58/05); V - Reticulophragmium gerochi Neagu et al. (Lipie 79/13/09); W Reticulophragmium amplectens (Grzybowski) (Gorlice 17/4/12); Y - Reticulophragmium amplectens (Grzybowski) (Gorlice 19/15/12); Z Reticulophragmium amplectens (Grzybowski) (Gorlice 7/4/12); AB - Popovia beckmanni (Kaminski et Geroch) (Stradomka 65/46/06); AC Popovia beckmanni (Kaminski et Geroch) (Gorlice 19/15/12); AD - Eggerelloides propinqus (Brady) (Gorlice 19/15/12); AE - Eggerelloides propinqus (Brady) (Stradomka 27/26/06); scale bar $100 \mu \mathrm{m}$ 
Istebna area, the increased number of Trochammina accompanies the assemblages of Glomospira Acme type (Fig. 3). Thus, the monospecific assemblages with Trochammina developed in the Silesian Basin since the Early Ypresian.

In the Early Eocene, a taxonomic restructuring of foraminiferal assemblages took place (e.g., Tjalsma and Lohman, 1983; Miller et al., 1987; Kaminski et al., 1989; Pak and Miller, 1992; Thomas and Shackleton, 1996; Thomas, 1998). In the Early or Middle Eocene, the species common in the Late Cretaceous and Paleocene had their last occurrences. These are, e.g., Caudammina ovula (Grzybowski), Annectina grzybowskii (Jurkiewicz), Caudammina excelsa (Dylążanka), Hormosina velascoensis (Cushman) and Glomospira diffundens Cushman et Renz, recorded as sporadic forms in the Ypresian part of the Hieroglyphic Beds (Fig. 5). Their occurrences within undiagnostic assemblages of agglutinated foraminifera are carriers of biostratigraphic information. Because of the widespread occurrence of assemblages with cosmopolitan and long-ranging species in the lower part of the Hieroglyphic Beds, biostratigraphic assignments are possible only by analysing faunal variability in a continuous sequence of samples.

Lutetian assemblages. Beginning from the Middle Eocene, there is a record of gradual changes successively expressed chiefly as an increase in taxonomical diversity and gradual reduction in uniform uncharacteristic foraminiferal assemblages. The Lutetian assemblages mark a transitory interval between taxonomically poor Ypresian assemblages, and the more diversified Bartonian and Priabonian assemblages. A characteristic feature of the Lutetian interval is the relatively numerous occurrence of Reticulophragmium amplectens (Grzybowski) (Figs. 3 and 13), continuing from the Lutetian and defining the biostratigraphic zone for which this species is an index taxon (e.g., Morgiel and Olszewska, 1981; Geroch and Nowak, 1984; Olszewska et al., 1996; Olszewska, 1997). The widespread and numerous occurrence of Reticulophragmium amplectens (Grzybowski) in Carpathian assemblages coincides with the disappearance of Saccamminoides carpathicus Geroch, with these two species co-occurring only in the late Ypresian (Olszewska et al., 1996; Olszewska, 1997; Kaminski and Gradstein, 2005; Waśkowska, 2011b). Assemblages with uncharacteristic cosmopolitan forminifera also occur in the Lutetian interval of the Hieroglyphic Beds (e.g., Stradomka, Olecka profiles). Determination of the boundary between the Ypresian and Lutetian based on foraminiferal assemblages is difficult. As a rule, in the Hieroglyphic Beds where the Ypresian interval is represented by thin-bedded flysch, foraminiferal assemblages are less diversified, sometimes making determination of the Ypresian zone impossible. In thick beds of shale intervals, the diversity increases markedly and the assemblages have features characteristic of the Reticulophragmium amplectens zone.

Bartonian and Priabonian assemblages. The Bartonian foraminiferal assemblages are diverse and usually contain biostratigraphically diagnostic forms. The index taxon for the Bartonian and Lutetian is Ammodiscus (Dolgenia) latus Grzybowski (Figs. 3 and 11) whose emergence in the Carpathians was reported from the Bartonian/Lutetian boundary zone (Jurkiewicz, 1967; Morgiel and Olszewska, 1981; Olszewska et al., 1996; Olszewska, 1997). Ammodiscus (Dolgenia) latus Grzybowski occurred until the end of the Eocene in the Outer Carpathians. It was accompanied by fairly large numbers of Reticulophragmium amplectens (Grzybowski). The stratigraphic determinant of the Priabonian is the presence of Reticulophragmium gerochi Neagu et al. This species has recently been separated from the Oligocene
Reticulophragmium rotundidorstaum (Hantken) (Neagu et al., 2011) which until 2011 had appeared under this name in the palaeontological literature. This form is reported from the upper part of the Hieroglyphic Beds or Green Shales from the Gorlice, Sucha Beskidzka, Rożnów Lake, and Ciężkowice areas (Książkiewicz, 1974b; Geroch et al., 1976; Szymakowska, 1979; Cieszkowski, 1992; Fig. 13). While Reticulophragmium amplectens (Grzybowski) and Ammodiscus (Dolgenia) latus Grzybowski are widespread in assemblages and represented by numerous specimens, Reticulophragmium gerochi Neagu et al. is found only in taxonomically diversified assemblages, indicating their development under favourable ecological conditions. Reticulophragmium gerochi Neagu et al. is usually a minor component in the assemblage. It is ephemeral and relatively rare in the Upper Eocene section. Therefore, in the Hieroglyphic Beds or Green Shales, the Upper Eocene interval is more often represented by the foraminiferal assemblage with Reticulophragmium amplectens (Grzybowski) and Ammodiscus (Dolgenia) latus Grzybowski, and it is not always possible to distinguish the Reticulophragmium rotundidorsatum (=gerochi) zone sensu Morgiel and Olszewska (1981), Geroch and Koszarski (1988) and Olszewska (1997). It should be taken into account during the age analysis. Because of great fluctuations in the faunal record of the Hieroglyphic Beds, the dating of these deposits, based on agglutinated foraminifera, provides reliable results only in case of a continuous depositional sequence. Dating of isolated samples can result in errors. In the Bartonian assemblages, and sporadically in the Lutetian assemblages from the Hieroglyphic Beds, foraminifers are rare in the Carpathians, e.g., Eggerelloides propinqus (Brady), Adercotryma agterbergi Gradstein et Kaminski, Buzasina pacifica (Krasheninnikov), Insculptarenula aff. subvesicularis (Hanzlíková), Spirosigmoilinella compressa Matsunaga and Thurammina occur sporadically (Figs. 5, 12 and 13), but the bulk of the assemblage is composed of species more common in the boreal basins of the Eocene. In the topmost part of the Hieroglyphic Beds/Green Shales, the carbonate content increases successively along with the occurrence of calcareous planktonic and benthic foraminifera. Subbotina div. sp., Globigerinatheka index (Finlay), Catapsydrax dissimilis Cushman et Bermúdez, Turborotalia increbescens (Bandy), Globigerina officinalis Subbotina, Globoturborotalia ouachitaensis (Howe et Wallace), Subbotina corpulenta (Subbotina), S. linaperta (Finlay) and S. yeguaensis (Weinzierl et Applin) are widespread (Waśkowska, 2015b).

\section{PALAEOECOLOGICAL IMPLICATIONS}

Restructuring of assemblages after the Late Paleocene-Early Eocene crisis. During the Early Eocene, the restructuring of benthic fauna assemblages took place in deep-water basins, which is well-marked in the Outer Carpathians (e.g., Bubik, 1995; Bąk, 2004; Waśkowska-Oliwa, 2005 and papers cited therein). This was a global trend associated with changes in Late Paleocene and Early Eocene palaeoclimate, especially thermal conditions (so-called PETM Paleocene Eocene Thermal Maximum) with the optimum in the Early Eocene (EECO) (e.g., Tjalsma and Lohman, 1983; Miller et al., 1987; Pak and Miller, 1992; Thomas and Shackleton, 1996; Thomas, 1998; Kennett and Stott, 1991; Kaiho et al., 1993, 1996; Pardo et al., 1999; Lourens et al., 2005; Agnini et al., 2009; Stap et al., 2010; Zachos et al., 2010; Pälike, 2012). These phenomena resulted in a massive extinction of benthic species in deep seas, and this event is recognized as the single largest global extinction of benthic fauna. The Eocene assem- 
blages are thus called "new post-crisis fauna" even though they contain many opportunistic long-lived forms functioning since the Cretaceous, which managed to survive the Late Paleocene crisis (Kaminski et al., 1996). In the Carpathian basins, the post-crisis assemblages are characteristic because their taxonomic diversity is lower, with numerous small forms of Glomospira among which two species predominate (e.g., Jurkiewicz, 1967; Bubik, 1995; Bąk et al., 1997; Waśkowska-Oliwa, 2000, 2011a; Bąk, 2004). The assemblages composed predominantly of Glomospira most often accompany hemipelagic, variegated deep-water deposits (e.g., Morgiel and Olszewska, 1981; Waśkowska-Oliwa, 2000; Bąk, 2004; Cieszkowski et al., 2011) in areas of low sedimentation rate (Kaminski et al., 1989). The reorganization of the assemblages structure took place gradually. It was a long-term process, lasting until the Middle Eocene and including gradual diversification of fauna representing various trophic groups that colonised epi- and infaunal niches. The restructuring of benthic fauna assemblages occurred in the late Early Eocene and was characterized by the occurrence of Saccamminoides carpathicus Geroch. The restructuring was not uniform and occurred at variable rates depending on a number of factors. The most important factor is environmental conditions. In the Flysch Outer Carpathians, the Early Eocene represents the Glomospira div. sp. zone which has properties of an acme zone, and the total range zone Saccamminoides carpathicus. Such an Early Eocene biostratigraphic scheme is barely recognizable within the Hieroglyphic Beds because uncharacteristic assemblages or small-sized Trochammina assemblages predominate in this interval (Waśkowska, 2015a).

In the Silesian Basin, the fauna stressed by the Late Paleocene crisis diversified very slowly in the Early Eocene. In the material analysed, assemblages characteristic of the Glomospira biofacies were found only in the Hieroglyphic Beds in the Istebna area; the higher proportions of Glomospira in the assemblages occur within the Early Eocene variegated deposits. Trochammina and Glomospira monospecific assemblages occupied similar ecological niches and developed in parallel in the Silesian Basin during the Early Eocene. The poor spread of assemblages with Glomospira could be an effect of the conditions limiting their functioning. They could, therefore, be replaced in the basin by more resistant associations with Trochammina (Waśkowska, 2015a). The structure of the assemblages of the Trochammina biofacies is fairly similar to that of the assemblages of the Glomospira biofacies. They differ chiefly in the type of predominant forms. As a rule, Glomospira monospecific assemblages in the Carpathians are recorded in hemipelagic claystones. These are often variegated deposits. In turn, Trochammina monospecific assemblages occur in grey-green shales or in thin-bedded flysch deposits characterized by a higher sedimentation rate than the variegated deposits, while in shale sequences the supply of material is permanent. Poorly diversified assemblages with numerous Trochammina specimens are a reflection of the specific conditions on the floor of the Early Eocene Silesian Basin. These assemblages represent the early phases of recolonization that took place after the Late Paleocene crisis, and maintain their form consistently throughout a fairly long time interval until the Middle Eocene. The slowing down of the recolonization process might have been affected, e.g., by sedimentation conditions that limited the diversification of foraminiferal assemblages. The same factors could have an effect on the distribution of assemblages with Saccamminoides carpathicus Geroch in the sedimentary environment of the Hieroglyphic Beds. As an exception, Saccamminoides carpathicus Geroch appears in the Hieroglyphic Beds. It occurs only among taxonomically di- versified assemblages. The most numerous specimens are obtained from samples of variegated shales. This species prefers and develops best in environments dominated by hemipelagic sedimentation (Waśkowska, 2011b). Saccamminoides carpathicus Geroch is recorded in variegated shales of the Silesian Nappe in areas of Ciężkowice Sandstone sedimentation (Jurkiewicz, 1959, 1967; Geroch and Koszarski, 1988). Jurkiewicz (1959) linked the occurrence of this species with the degree of sanding. The most numerous specimens of this species are found in red deposits within the Ciężkowice Sandstone, whereas in the green shales, they are rare and represented by large and well-developed forms. In turn, they are very rare in sandy shales.

Beginning from the Middle Eocene, more taxonomically diversified assemblages appear in the Hieroglyphic Beds, represented by infaunal and epifaunal morphogroups confirming the improvement of ecological conditions at the sea-floor. To a great extent, the Middle and Late Eocene biostratigraphic zones are based on the first occurrences of forms new to the Silesian Basin, which found favourable living conditions. Also observed is an influx of new species that began to occur in the assemblages from the Middle Eocene.

Foraminiferal assemblages of the Hieroglyphic Beds in the face of long-term Eocene cooling. The Eocene was a time of major climate changes. In the Early Eocene, a climatic optimum (EECO) occurred, typified by the highest temperatures in the Cenozoic, whereas less than 20 million years later, in the Early Oligocene, an ice sheet developed in Antarctica (e.g., Miller et al., 1987; 2005; Coxall et al., 2005; Ortiz and Thomas, 2006; Zachos et al., 2006; Lear et al., 2008; Galazzo et al., 2013). In the Eocene, a long-term successive climate cooling (e.g., Zachos et al., 2001, 2008; Katz et al., 2008; Bijl et al., 2010), called the "doubthouse" state, took place between the "greenhouse" conditions of the early Paleogene and the "icehouse" regime (Galazzo et al., 2013). The trend of global cooling was interrupted by warming episodes, among which the longest and most intensive was the Middle Eocene Climatic Optimum (MECO; e.g., Bohaty and Zahos, 2003; Bohaty et al., 2009; Edgar et al., 2010; Savian et al., 2011; Galazzo et al., 2013; Sluijs et al., 2013). A period of gradual but important faunal turnover associated with climate changes is marked in the world's ocean beginning from the Middle Eocene (e.g., Corliss, 1981; Keller, 1983a, b, 1986; Miller et al., 1987; Miller, 1992; Zachos et al., 2001; Ortiz and Thomas, 2006).

In the foraminiferal assemblages of the Silesian Nappe sensu lato, fundamental changes associated with global cooling and bathymetrical fluctuations are marked in the Late Eocene. The effects included the development of calcareous Globigerina Marls (e.g., Olszewska, 1983, 1984; Leszczyński, 1996,1997 and papers cited therein) containing fauna dominated by planktonic and calcareous benthic forms (e.g., Bieda, 1946; Blaicher, 1961, 1967, 1970; Olszewska, 1983, 1984), which are utterly different from the assemblages from underlying beds. The period including the sedimentation of the upper part of the Hieroglyphic Beds or Green Shales is a transitional interval within which gradual changes proceeded in foraminiferal assemblages, from the ones exclusively comprised of agglutinated foraminifera into the assemblages composed predominantly of calcareous foraminifera. In the agglutinated assemblages, the quantities of plankton and calcareous benthos increase gradually, which is noticeable in sediments deposited by suspension. The change in the character of assemblages is marked in the uppermost several metres of the analysed subdivisions. In the Upper Eocene deposits, which are dominated by thin-bedded flysch, the Globigerina Marls are missing. This phenomenon can be observed in the western part 
of the Polish Carpathians, and in the Czech Republic. In some areas of the Silesian Basin, the flysch sedimentation diluted calcareous material and limited the deposition of calcareous deposits that are typical of the Globigerina Marls. The foraminiferal assemblages from these deposits are represented by unified associations containing only non-characteristic cosmopolitan forms of agglutinated foraminifera.

The progressive decrease in temperatures in the Eocene was a factor motivating the migration of species. During the Eocene, a turnover in species composition occurred within the cosmopolitan benthic fauna. Along with progressive cooling, new cool-water preferring forms migrated from the boreal basins to the Carpathian Silesian Basin, whereas the latter basin was gradually abandoned by thermophilous species.

Beginning from the Middle Eocene, an influx of new species is recorded in the Hieroglyphic Beds. They include, inter alia, the index forms Reticulophragmium amplectens (Grzybowski), Ammodiscus (Dolgenia) latus Grzybowski and Reticulophragmium gerochi Neagu et al. These species reached their optimum development in the Eocene in the temperate zones of Atlantic and Tethyan basins. In the Oligocene, they were well-developed in the cool climate of boreal basins where they were present for the longest time. In the subarctic region, Reticulophragmium amplectens (Grzybowski) and Ammodiscus (Dolgenia) latus Grzybowski continued to occur until the Middle and Late Miocene (Osterman and Spiegler, 1996; Kaminski et al., 2005). In optimum climatic conditions, in the boreal basins, Ammodiscus (Dolgenia) latus Grzybowski reaches over $2 \mathrm{~mm}$ across (Kaminski et al., 1989), while in the warmer Carpathian basins, it was less than half that size.

The progressive climate cooling was accompanied by ephemeral occurrences of rare species, i.e., Eggerelloides propinqus (Brady), Eratidus gerochi Kaminski et Gradstein, Adercotryma agterbergi Gradstein et Kaminski, Ammomarginulina aubertae Gradstein et Kaminski, Insculptarenula aff. subvesicularis (Hanzlíková), Spirosigmoilinella compressa Matsunaga, Thurammina sp. and Reophanus berggreni Gradstein et Kaminski (Figs. 5, 12 and 13). In part, these taxa are known from the boreal basins where they are much more common (Gradstein and Kaminski, 1997; Kaminski and Austin, 1999; Kaminski and Gradstein, 2005; Bubik and Waśkowska-Oliwa, 2005; Waśkowska, 2014b). These species migrated into the Carpathian basins from the north, and they found favourable living conditions in the Eocene during the slow climate cooling. The routes of these migrations, associated with the existence of connections between the Carpathian basins and boreal basins, constitute a separate issue.

In turn, there is a gradual disappearance of species belonging to the genus Karrerulina in the Eocene deposits of the Carpathians. For example, Karrerulina coniformis (Grzybowski), a typical Eocene species, is progressively less numerous towards the top of the Hieroglyphic Beds. Karrerulina conversa (Grzybowski) which is common in the Late Cretaceous and Paleocene, gradually disappear after the Middle Eocene (e.g., Gradstein and Berggren, 1981; Kaminski and Gradstein, 2005). In the boreal basins, its last occurrence was in the Middle Eocene, whereas in the areas of Trinidad, Morocco, Angola, India, and the South China Sea, it is present until the Oligocene (Kuhnt et al., 2002; Kaminski and Gradstein, 2005; Kender et al., 2008), finding there suitable conditions for life. Beginning in the Middle Eocene, Buzasina pacifica (Krasheninnikov) ceases to occur in the Hieroglyphic deposits. Its last occurrence is recorded in the Middle Eocene Ammodiscus (Dolgenia) latus zone. Kalamopsis grzybowskii (Dylążanka), widespread in the
Cretaceous and Paleogene deposits of the Carpathians, is a minor component in the Hieroglyphic deposits and disappears progressively. In the Oligocene, this species was recorded in the South China Sea (Kuhnt et al., 2002; Holbourn et al., 2013). Another species that preferss warm water is Haplophragmoides nauticus Kender, Kaminski et Jones. This species is known and described from the Oligocene in Angola (Kender et al., 2006, 2008) and occurs commonly in the Carpathian Eocene (Waśkowska-Oliwa, 2008; Golonka and Waśkowska, 2012), while the Late Paleocene/Early Eocene deposits contain transitional forms between Haplophragmoides nauticus Kender et al. and $H$. walteri (Grzybowski) (Waśkowska, 2008). The migration of this species to the south is possible although too little is known about its stratigraphical and geographical distribution.

The next manifestation of the Eocene climatic changes is the extinction of forms that had survived the Early Eocene crisis (EECO). Caudammina ovula (Grzybowski) and Hormosina velascoensis (Cushman), still found in the Early Eocene (e.g., Jurkiewicz, 1967; Bąk 2004; Waśkowska, 2011a, b, 2015a; Figs. 5 and 11) and Middle Eocene (Kaminski and Gradstein, 2005; Holbourn et al., 2013) deep-water deposits, are also present in the Hieroglyphic deposits. Despite their survival in adverse conditions, they did not rebuild their positions in assemblages and disappeared from the palaeontological record. Such forms should also include Annectina grzybowskii (Jurkiewicz), Glomospira diffundens Cushman et Renz and Caudammina excelsa (Dylążanka), which still occur in the post-crisis Early Eocene assemblages (e.g., Jurkiewicz, 1967; Bąk, 2004; Kaminski and Gradstein, 2005; Waśkowska, 2011a, b, 2015a; Waśkowska and Cieszkowski, 2014).

Foraminiferal assemblages vs. sedimentation regime. Beginning in the Middle or Late Eocene, the sedimentation regime within the Silesian Basin underwent gradual changes. In part of the basin, the sedimentation of Green Shales occurred, with a major effect of suspension (Waśkowska, 2014b). This is the interval from which diversified assemblages and diagnostic species for age determination are obtained. The sedimentation regime had an enormous effect upon the formation of the agglutinated fauna living on the sea-floor. The flysch sedimentation is coupled with the supply of variously sized clastic material to the basin. It is often associated with the massive deposition of psammite and psephite material in the form of concentrated sandstone and conglomerate layers. The deposition of each layer significantly disturbs the conditions in the near-bottom zone and destroys the associations of small organisms which had colonized the sea-floor after the last descent of a suspension current. Apart from the availability of food- and oxygen-providing nutrients, it is the sedimentation regime which is primarily responsible for the development of foraminiferal assemblages in deep-sea conditions. It includes the frequency of suspension currents, their strength, and the quantity of deposited material. The descent of each suspension current is followed by recolonization, and - as proved by the faunal record - it is a short-lasting and well-organised process, even though the frequent disturbances associated with suspension currents, repeated in a quick succession, create constraints on the development of foraminiferal assemblages. Assemblages tolerant to such environmental conditions exist at such times. They are composed of agglutinated, cosmopolitan forms, most often having coarse-grained and massive tests. For this reason, the faunal record is modelled by the sedimentary environment in flysch intervals of the Hieroglyphic Beds. In the areas covered by turbidite shale-sandstone sediments, cosmopolitan assemblages with few characteristic properties were formed, whereas 
in the areas of calmer shale sedimentation, there were more diverse assemblages of complex trophic structures.

\section{CONCLUSIONS}

In the Silesian Basin, the Hieroglyphic Beds developed from the Early and Middle Eocene until the Late Eocene. Their lower boundary is conditioned by the development of the directly underlying Ciężkowice Sandstone. In the western part of the Polish Carpathians, the Ciężkowice Sandstone disappears progressively and the sedimentation of the Hieroglyphic Beds occurs directly on the upper shales of the Istebna Beds. In these places, its sedimentation took place at least from the Ypresian. The upper boundary in the Bartonian is isochronous. It is marked by the Globigerina Marls horizon. In areas where the Globigerina Marls are absent, as they are locally diluted by flysch-type sedimentation, the Hieroglyphic Beds contact directly with the overlying Menilite Beds. The lower and upper boundary sequences are relatively thin, except in western regions where the transitional complexes are extended, and the boundaries between the units are conventional.

The Hieroglyphic Beds are generally dominated by turbidite shale-sandstone deposits, although there are major lateral differences in their development, not only in terms of variable number and thickness of sandstone intercalations, and diversification within the shales, but also in terms of diverse thick sandstone-free complexes that occur in the eastern part of the study area. They are correlated with one another, occupying similar lithostratigraphic positions (starting from the Bartonian or Lutetian) and are established as a separate subdivision of the Green Shales which disappear towards the western part of the study area. Such complexes are also found in other lithostratigraphic positions in the Lower and Middle Eocene. They usually contain irregularly distributed packets of variegated shales without wide lateral continuity. At some places, there are bentonite laminations testifying to suspension-dominated sedimentation, with a limited supply of terrigenous material.

The foraminiferal assemblages from the Hieroglyphic Beds are dominated by uniform assemblages of agglutinated cosmopolitan species with massive tests. The sedimentation regime had a major effect on their development. The Lower Eocene assemblages contain commonly small and numerous Trochammina, representing post-crisis assemblages following the PETM event. These assemblages replace small-sized Glomospira div. sp., as well as assemblages with Saccamminoides carpathicus Geroch commonly developed in the Lower Ypresian in other Carpathian basins. The assemblages dominated by Glomospira colonized areas under suspension-type sedimentation, with a limited supply of material from land, whereas the assemblages with Trochammina lived in conditions involving an increased sedimentation rate as well as a higher supply of terrigenous material. Beginning from the Mid- dle Eocene, the foraminiferal assemblages became more taxonomically diversified. In the Lutetian, the assemblages with Reticulophragmium amplectens (Grzybowski) are common. Beginning from the Bartonian, Reticulophragmium amplectens (Grzybowski) is accompanied by Ammodiscus (Dolgenia) latus Grzybowski, while in the Priabonian there are rare occurrences of Reticulophragmium gerochi Neagu et al. Because of the somewhat ephemeral appearances of Reticulophragmium gerochi Neagu et al. defining the zone, it is not always possible to establish a standard for the Carpathian deposits for which it is an index species.

The assemblages from the Hieroglyphic Beds reveal taxonomic changes associated with the long-term Eocene climatic cooling that stimulated inter-basin migrations of fauna. Warm water-preferring forms, i.e., Karrerulina coniformis (Grzybowski), Karrerulina conversa (Grzybowski), Buzasina pacifica (Krasheninnikov) and Kalamopsis grzybowskii (Dylążanka), gradually disappeared in the Eocene assemblages of the Silesian Basin. In turn, the Silesian Basin was colonized by species adapted to life in cool waters, including universal stratigraphic index species, such as Reticulophragmium amplectens (Grzybowski), Ammodiscus (Dolgenia) latus Grzybowski and Reticulophragmium gerochi Neagu et al., as well as rare forms, i.e., Eggerelloides propinqus (Brady), Eratidus gerochi Kaminski et Gradstein, Adercotryma agterbergi Gradstein et Kaminski, Ammomarginulina aubertae Gradstein et Kaminski, Insculptarenula aff. subvesicularis (Hanzlíková), Spirosigmoilinella compressa Matsunaga, and Reophanus berggreni Gradstein et Kaminski. The environmental conditions during the gradual climatic changes were not favourable for the restructuring of the foraminiferal associations decimated by the PETM crisis. Caudammina ovula (Grzybowski), Hormosina velascoensis (Cushman), Annectina grzybowskii (Jurkiewicz), Glomospira diffundens Cushman et Renz and Caudammina excelsa (Dylążanka) still occurred in the post-crisis Early or Middle Eocene assemblages, and then disappeared from the palaeontological records. The definite restructuring of foraminiferal assemblages within the Hieroglyphic Beds took place in the Priabonian, in the uppermost part overlain by the Globigerina Marls. In the assemblages occupying the last several metres of the profile, there is an evident increase in calcareous benthic and planktonic forms that become predominant components.

Acknowledgments. The thanks are addressed to J. Golonka (AGH) for helpful discussion, as well as to reviewers M.A. Kaminski (KFUPM), R. Chodyń (UJ) and L. Jankowski (PGI-NRI) for constructive comments to manuscript. The author is grateful to T. Wójcik $(A G H)$ and Z. Górny $(A G H)$ for laboratory work. M. Czuj-Górniak (AGH), R. Stadnik (AGH), S. Bębenek $(\mathrm{AGH}), \mathrm{R}$. Chodyń (UJ), E. Waśkowska and K. Oliwa helped with the field work. This research has been financially supported by AGH University of Science and Technology in Kraków grant No. 11.11.140.173.

\section{REFERENCES}

Agnini, C., Muttoni, G., Kent, D.V., Rio, D., 2006. Eocene biostratigraphy and magnetic stratigraphy from Possagno, Italy: The calcareous nannofossil response to climate variability. Earth and Planetary Science Letters, 241: 815-830.
Agnini, C., Macri, P., Backman, J., Brinkhuis, H., Fornaciari, E., Giusberti, L., Luciani, V., Rio, D., Sluijs, A., Speranza, F., 2009. An early Eocene carbon cycle perturbation at $\sim 52.5 \mathrm{Ma}$ in 
the Southern Alps: chronology and biotic response. Paleoceanography, 24, doi:10.1029/2008PA001649

Bąk, K., 2004. Deep-water agglutinated foraminiferal changes across the Cretaceous/Tertiary and Paleocene/Eocene transitions in the deep flysch environment; eastern Outer Carpathians (Bieszczady Mts, Poland). Grzybowski Foundation Special Publication, 8: 1-56.

Bąk, K., Bąk, M., Geroch, S., Manecki, M., 1997. Biostratigraphy and paleoenvironmental analysis of benthic foraminifera and radiolarians in Paleogene variegated shales in the Skole unit, Polish Flysch Carpathians. Annales Societatis Geologorum Poloniae, 67: 135-154.

Bieda, F., 1946. La stratigraphie du Flysch des Karpates centrales polonaises basée sur les grands Foraminifčres (in Polish with French summary). Rocznik Polskiego Towarzystwa Geologicznego, 16: 1-52.

Bieda, F., Geroch, S., Koszarski, L., Książkiewicz, M., Żytko, K., 1963. Stratigraphie des Karpates Externes Polonaises (in French). Kwartalnik Instytutu Geologicznego, 181: 1-174.

Bijl, P.K., Houben, A.J.P., Schouten, S., Bohaty, S.M., Sluijs, A., Reichart, G.J., Sinninghe Damsté, J.S., Brinkhuis, H., 2010. Transient middle Eocene atmospheric $\mathrm{CO}_{2}$ and temperature variations. Science, 330: 819-821.

Blaicher, J., 1961. Microfauna of Globigerina marls of region of Podzamcze Fold (Carpathians) (in Polish with English summary). Kwartalnik Geologiczny, 5: 602-611.

Blaicher, J., 1967. Assemblages of small foraminifera from the Sub-menilite Globigerina Marls in the Carpathians. Biuletyn Instytutu Geologicznego, 211: 355-364.

Blaicher, J., 1970. Globigerinae of the Sub-Menilite Globigerina Marls (in Polish with English summary). Biuletyn Instytutu Geologicznego, 221: 137-175.

Bohaty, S.M., Zachos, J.C., 2003. A significant Southern Ocean warming event in the late middle Eocene. Geology, 31: 1017-1020.

Bohaty, S.M., Zachos, J.C., Florindo, F., Delaney, M.L., 2009. Coupled greenhouse warming and deep-sea acidification in the middle Eocene. Paleoceanography, 24, doi: 10.1029/2008PA001676

Bubik, M., 1995. Cretaceous to Paleogene agglutinated foraminifera of the Biele Karpaty unit (West Carpathians, Czech Republic). Grzybowski Foundation Special Publication, 3: 71-116.

Bubik, M., 2007. Results of mapping and stratigraphic research in the Silesian Unit on the Horní Bečva map sheet (in Czech with English summary). Zprávy o geologických výzkumech $v$ roce 2006: 9-14.

Bubik, M., Waśkowska-Oliwa, A., 2005. Boreal agglutinated foraminifera in the Paleogene of the Outer Flysch Carpathians: preliminary results. In: Seventh International Workshop on Agglutinated Foraminifera - Abstracts volume (eds. R. Coccioni, M.A. Kaminski and A. Marsili): 9-11. Institutio di Geologia, Universita degli Studi di Urbino, Urbino.

Burtan, J., 1936. Stratigraphie der Schlesischen Beskiden. Bulletin International de l'Academie Polonaise des Sciences et des Lettres, Classe des Sciences Mathematiques et Naturelles, Serie A, 41: 195-209.

Burtan, J., 1954. Szczegółowa Mapa Geologiczna Polski, 1:50 000, arkusz Wieliczka (in Polish). Wyd. Geol., Warszawa.

Burtan, J., 1964a. Szczegółowa Mapa Geologiczna Polski, Region Karpat i Przedgórza, wydanie tymczasowe, 1:50 000, arkusz Wieliczka (in Polish). Wyd. Geol., Warszawa.

Burtan, J., 1964b. Szczegółowa Mapa Geologiczna Polski, Region Karpat i Przedgórza, wydanie tymczasowe, 1:50 000, arkusz Myślenice (in Polish). Wyd. Geol., Warszawa.

Burtan, J., 1964c. Szczegółowa Mapa Geologiczna Polski, Region Karpat i Przedgórza, wydanie tymczasowe, 1:50 000, arkusz Mszana Dolna (in Polish). Wyd. Geol., Warszawa.

Burtan, J., 1972. Szczegółowa Mapa Geologiczna Polski, 1:50 000, arkusz Wisła (in Polish). Wyd. Geol., Warszawa.
Burtan, J., 1973. Objaśnienia do Szczegółowej Mapy Geologicznej Polski, 1:50 000, arkusz Wisła (in Polish). Wyd. Geol., Warszawa.

Burtan, J., 1974. Szczegółowa Mapa Geologiczna Polski, 1:50 000, arkusz Mszana Dolna (in Polish). Wyd. Geol., Warszawa.

Burtan, J., 1978. Objaśnienia do Szczegółowej Mapy Geologicznej Polski, 1:50 000, arkusz Mszana Dolna (in Polish). Wyd. Geol., Warszawa.

Burtan, J., Skoczylas-Ciszewska, K., 1964a. Szczegółowa Mapa Geologiczna Polski, Region Karpat i Przedgórza, wydanie tymczasowe, 1:50 000, arkusz Męcina (in Polish). Wyd. Geol., Warszawa.

Burtan, J., Skoczylas-Ciszewska, K., 1964b. Szczegółowa Mapa Geologiczna Polski, Region Karpat i Przedgórza, wydanie tymczasowe, 1:50 000, arkusz Limanowa (in Polish). Wyd. Geol., Warszawa.

Burtan, J., Skoczylas-Ciszewska, K., 1964c. Szczegółowa Mapa Geologiczna Polski, Region Karpat i Przedgórza, wydanie tymczasowe, 1:50 000, arkusz Bochnia (in Polish). Wyd. Geol., Warszawa.

Burtan, J., Szymakowska, F., 1964. Szczegółowa Mapa Geologiczna Polski, Region Karpat i Przedgórza, wydanie tymczasowe, 1:50 000, arkusz Osielec (in Polish). Wyd. Geol., Warszawa.

Burtan, J., Sokołowski, S., Sikora, W., Żytko, K., 1956. Szczegółowa Mapa Geologiczna Polski,1:50 000, arkusz Milówka (in Polish). Wyd. Geol., Warszawa.

Burtanówna, J., 1933. Der Geologische Bau der Umgegenden von Myślenice westlich von Raba - Fluss (in Polish with German summary). Rocznik Polskiego Towarzystwa Geologicznego, 9: 279-293.

Burtanówna, J., Konior, K., Książkiewicz, M., 1937. Carte géologique des Karpates de Silesie (in Polish with French summary). Wydawnictwa Śląskie, Polska Akademia Umiejętności, Kraków.

Charnock, M.A., Jones, R.W., 1990. Agglutinated foraminifera from the Paleogene of the North Sea. NATO ASI Series C, Mathematical and Physical Sciences, 327: 139-244.

Chodyń, R., Waśkowska-Oliwa, A., 2006. Lithostratigraphy and biostratigraphy of the Paleocene-Early Oligocene flysch sediments in the western part of the Szczyrzyc Synclinorium, Silesian Nappe (Polish Outer Carpathians). Scientific Annals of the School of Geology, Aristole University of Thessaloniki, Belgrade, Serbia, Special Volume, 100: 57-60.

Cieszkowski, M., 1986. Stop 2. Obidowa. In: Przewodnik LVII Zjazdu Polskiego Towarzystwa Geologicznego, Pieniny 18-20 września 1986 (in Polish) (eds. K. Birkenmajer and D. Poprawa): 36-44. Zakład Geologii AGH, Kraków.

Cieszkowski, M., 1992. Michalczowa zone: a new unit of Fore-Magura zone, Outer Carpathians, South Poland (in Polish with English summary). Geologia - Kwartalnik AGH,18: 1-125.

Cieszkowski, M., Waśkowska, A., 2013a. Olistostrome deposits in the Eocene Hieroglyphic Formation (Silesian Nappe, Outer Carpathians). In: Geological evolution of the Western Carpathians: new ideas in the field of inter-regional correlations (eds. I. Broska and A. Tomasovych). Abstracts Book, Geological Institute, Slovak Academy of Sciences: 42-43.

Cieszkowski, M., Waśkowska, A., 2013b. Olistostrome deposits in the Eocene Hieroglyphic Formation (Silesian Nappe, Outer Carpathians). Grzybowski Foundation Special Publication, 19: 10-11.

Cieszkowski, M., Ślączka, A., Wdowiarz, S., 1985. New data on structure of the flysch Carpathians. Przegląd Geologiczny, 33: 313-333.

Cieszkowski, M., Koszarski, A., Leszczyński, S., Michalik, M., Radomski, A., Szulc A., 1991. Szczegółowa Mapa Geologiczna Polski, 1:50 000, arkusz Ciężkowice (in Polish). Wyd. Geol., Warszawa.

Cieszkowski, M., Golonka, J., Waśkowska-Oliwa, A., Chrustek, M., 2006a. Geological structure of the Sucha Beskidzka region - 
Świnna Poręba (Polish Flysch Carpathians) (in Polish with English summary). Geologia - Kwartalnik AGH, 32: 155-201.

Cieszkowski, M., Leśniak,T., Środoń, J., Waśkowska-Oliwa, A., 2006b. Bentonitized tuffites in the Lower Eocene deposits of the Subsilesian Unit (Western Outer Carpathians, Poland). Annales Societatis Geologorum Poloniae, 76: 197-214.

Cieszkowski, M., Golonka, J., Krobicki, M., Ślączka, A. Oszczypko, N., Waśkowska, A., Wendorff, M., 2009. The Northern Carpathian plate tectonic evolutionary stages and origin of olistolithes and olistostromes. Geodinamica Acta, 22 101-126.

Cieszkowski, M., Waśkowska, A., Kaminski, M.A., 2011 Deep-water agglutinated foraminifera in Paleogene hemipelagic sediments of the Magura Basin in the Sucha Beskidzka area - variegated shales of the Łabowa Shale Formation. Grzybowski Foundation Special Publication, 17: 53-63.

Corliss, B.H., 1981. Deep-sea benthonic foraminiferal faunal turnover near the Eocene/Oligocene boundary. Marine Micropaleontology, 6: 367-384.

Coxall, H.K., Wilson, P.A., Palike, H., Lear, C.H., Backman, J., 2005. Rapid stepwise onset of Antarctic glaciation and deeper calcite compensation in the Pacific Ocean. Nature, 433: 53-57.

Czaplicka, J., Juskowiak, O., Ryka, W., Kilian, Z, Tomczykowa, E., Tomczyk, H., Pajchlowa, M., Stopa, S. Z., Kozłowski, S., Kotański, Z., Kopik, J., Malinowska, L., Ciesliński, S., Woźny E., Głodek, J., Krajewski, S., 1968. Słownik stratygraficzny (in Polish). Wyd. Geol., Warszawa.

Edgar, K.M., Wilson, P.A., Sexton, P.F., Gibbs, S.J., Roberts A.P., Norris, R.D., 2010. New biostratigraphic, magnetostratigraphic and isotopic insights into the middle Eocene climatic optimum in low latitudes. Palaeogeography, Palaeoclimatology, Palaeoecology, 297: 670-682.

Eliáš, M., 1979. Facies and paleogeography of the Silesian unit in the western part of the Outer Czechoslovak Carpathians. Vestnik Ustredniho Ustavu Geologickeho, 54: 327-339.

Eliáš, M., 2001. Rožnovskésouvrství - nové formálníoznačení pro podmenilitové souvrství godulského vývoje slezské jednotky (Moravskoslezské Beskydy, Kelčská pahorkatina, vnější Západní Karpaty) (in Czech). Geologické výzkumy na Moravě a ve Slezku v roce 2000, 8: 18-22.

Galazzo, B.F., Giusberti, L., Luciani, V., Thomas, E., 2013. Paleoenvironmental changes during the Middle Eocene Climatic Optimum (MECO) and its aftermath: The benthic foraminiferal record from the Alano section (NE Italy). Palaeogeography, Palaeoclimatology, Palaeoecology, 378: 22-35.

Geroch, S., 1955. Sacamminoides n. gen. (Foraminiferida) from the Eocene in the Flysch Carpathians. Rocznik Polskiego Towarzystwa Geologicznego, 23: 53-63.

Geroch, S., 1960. Microfaunal assemblages from the Cretaceous and Paleogene Silesian Unit in the Beskid Ślaski Mts. (Western Carpathians) (in Polish with English summary). Biuletyn Instytutu Geologicznego, 153: 7-73.

Geroch, S., Koszarski L., 1988. Agglutinated foraminiferal stratigraphy of the Silesian flysch trough. Abhandlungen der Geologischen Bundesanstalt, 41: 73-79.

Geroch, S., Nowak, W., 1984. Proposal of zonation for the late Tithonian-late Eocene, based upon arenaceous Foraminifera from the Outer Carpathians, Poland. In: Benthos '83, (ed. H.J. Oertli): 2nd International Symposium on Benthic Foraminifera Pau (France). Elf Aquitane, ESSO REP and TOTAL CFP, Pau \& Bordeaux, 225-239.

Geroch, S., Jednorowska, A., Książkiewicz, M., Liszkowa, J. 1967. Stratigraphy based upon microfauna in the Western Polish Carpathians. Biuletyn Instytutu Geologicznego, 211: 185-282.

Golonka, J., 1981. Objaśnienia do Szczegółowej Mapy Geologicznej Polski, 1:200 000, arkusz Bielsko-Biała (in Polish). Wyd. Geol., Warszawa.

Golonka, J., 2011. Evolution of the Outer Carpathian Basins. Grzybowski Foundation Special Publication, 17: 3-14.
Golonka, J., Waśkowska, A., 2012. The Beloveža Formation of the Raca Unit in the Beskid Niski Mts.(Magura Nappe, Polish Flysch Carpathians) and adjacent parts of Slovakia and their equivalents in the western part of the Magura Nappe; remarks on the Beloveža Formation - Hieroglyphic Beds controversy. Geological Quarterly, 56 (4): 821-832.

Golonka, J., Waśkowska-Oliwa, A., 2007. Stratigraphy of the Polish Flysch Carpathians between Bielsko-Biała and Nowy Targ (in Polish with English summary). Geologia - Kwartalnik AGH, 33: 5-28.

Golonka, J., Borysławski, A., Paul, Z., Ryłko, W., 1979. Szczegółowa Mapa Geologiczna Polski, 1:200 000, arkusz Bielsko-Biała (in Polish). Wyd. Geol., Warszawa.

Golonka, J., Gahagan, L., Krobicki, M., Marko, F., Oszczypko, N., Slaczka, A., 2006. Plate tectonic evolution and paleogeography of the Circum-Carpathian Region. AAPG Memoir, 84: 11-46.

Golonka, J., Krobicki, M., Waśkowska-Oliwa, A., Vašíček, Z., Skupien, P., 2008. Main paleogeographical elements of the West Outer Carpathians during Late Jurassic and Early Cretaceous times. Geologia - Kwartalnik AGH, 34: 61-72.

Golonka, J., Ślączka, A., Waśkowska, A., Krobicki, M., Cieszkowski, M., 2013. Budowa geologiczna zachodniej części polskich Karpat zewnętrznych (in Polish). In: Głębokomorska sedymentacja fliszowa - sedymentologiczne aspekty historii basenów karpackich (eds. M. Krobicki and A. Feldman-Olszewska): 11-62. V Polska Konferencja Sedymentologiczna. Państwowy Instytut Geologiczny -Państwowy Instytut Badawczy, Warszawa.

Gradstein, F.M., Berggren, W.A., 1981. Flysch-type agglutinated foraminifera stratigraphy and the Maastrichtian to Paleogene history of the Labrador and North Seas. Marine Micropaleontology, 6: 211-268.

Gradstein F.M., Kaminski, M.A., 1997. New species of Paleogene deep-water agglutinated foraminifera from the North Sea and Norwegian Sea. Annales Societatis Geologorum Poloniae, 67: 217-229.

Grzybowski, J., 1921. Ciężkowice grès (in Polish with French summary). Kosmos, 46: 222-226.

Guzik, K., Pożaryski, W., 1949. Biecz Anticline (Middle Carpathians) (in Polish with English summary). Biuletyn Państwowego Instytutu Geologicznego, 53: 1-33.

Holbourn, A.,Henderson, A.S., Macleod, N., 2013. Atlas of Benthic Foraminifera. Wiley-Blackwell.

Jednorowska, A., 1968. Les associations des foraminiféres des zones externs de l'unite de Magura des Carpathes et leur importance stratigraphique (in Polish with French summary). Prace Geologiczne, 50: 1-89

Jurkiewicz, H., 1959. Microfaunal correlation in the Paleogene of the eastern part of the Silesian nappe (in Polish with English summary). Rocznik Polskiego Towarzystwa Geologicznego, 29: 235-263.

Jurkiewicz, H., 1967. Foraminifers in the Sub-Menilitic Palaeogene in the Polish Middle Carpathians (in Polish with English summary). Biuletyn Instytutu Geologicznego, 210: 5-128.

Kaiho, K., Morgans, E. G., Okada, H., 1993. Faunal turnover of intermediate-water foraminifera during the Paleogene in New Zealand. Marine Micropaleontology, 23: 51-86.

Kaiho, K., Arinobu, T., Ishiwatari, R., Morgans, H. E. G., Okada, H., Takeda, N., Tazaki, K., Zohu, G., Kajiwara, Y., Matsumoto, R., Hirai, A., Niitsuma, N., Wada, H., 1996. Latest Paleocene benthic foraminiferal extinction and environmental changes at Tawanui, New Zealand. Paleoceanography, 11: 447-465.

Kaminski, M.A., Austin, W.E.N., 1999. Oligocene deep-water agglutinated foraminifers at Site 985, Norwegian Basin, southern Norwegian Sea. Proceedings of the Ocean Drilling Program, Scientific Results, 162: 169-177

Kaminski, M.A., Geroch, S., 1987. Two new species of Phenacophragma from the Paleogene of the Trinidad and Poland. Micropaleontology, 33: 185-188. 
Kaminski, M.A., Gradstein, F.M., 2005. Atlas of Paleogene Cosmopolitan Deep-Water Agglutinated Foraminifera. Grzybowski Foundation Special Publication, 10: 1-547.

Kaminski, M.A., Ortiz, S. 2014. The Eocene-Oligocene turnover of deep-water agglutinated foraminifera at ODP Site 647 , Southern Labrador Sea (North Atlantic). Micropaleontology, 61: 53-66.

Kaminski, M.A., Gradstein, F.M., Berggren, W.A., 1989. Paleogene benthic foraminifer biostratigraphy and paleoecology at Site 647,southern Labrador Sea. Proceedings of the Ocean Drilling Program, Scientific Results, 105: 705-730.

Kaminski, M.A., Kuhnt, W., Radley, J.D., 1996. Palaeocene-Eocene deep water agglutinated foraminifera from the Numidian Flysch (Rif, Northern Marocco): their significance for the palaeoceanography of the Gibraltar gateway. Journal of Micropalaeontology, 15: 1-19.

Kaminski, M.A., Silye, L., Kender, S. 2005. Miocene deep-water agglutinated foraminifera from ODP Hole 909C: Implications for the paleoceanography of the Fram Strait area, Greenland Sea. Micropaleontology, 51: 373-403.

Katz, M.E., Miller, K.G., Wright, J.D., Wade, B.S., Browning, J.V., Cramer, B.S., Rosenthal,Y., 2008. Stepwise transition from the Eocene greenhouse to the Oligocene icehouse. Nature Geoscience, 1: 329-334.

Keller, G.,1983a. Biochronology and paleoclimatic implications of middle Eocene to Oligocene planktic foraminiferal faunas. Marine Micropaleontology, 7: 463-486.

Keller, G.,1983b. Paleoclimatic analysis of middle Eocene through Oligocene planktonic foraminiferal faunas. Palaeogeography, Palaeoclimatology, Palaeoecology, 43: 73-94.

Keller, G., 1986. Stepwise mass extinctions and impact events: late Eocene and early Oligocene. Marine Micropaleontology,13: 267-293.

Kender, S., Kaminski, M.A., Jones, R.W., 2006. Four new species of deep-water agglutinated foraminifera from the Oligocene-Miocene of the Congo Fan (offshore Angola). Micropaleontology, 52: 465-470.

Kender, S., Kaminski, M.A., Jones, R.W., 2008. Oligocene deep-water agglutinated foraminifera from the Congo Fan, Offshore Angola: Palaeoenvironments and assemblage distributions. Grzybowski Foundation Special Publication, 13: 107-156.

Kennett, J.P., Stott, L.D., 1991. Abrupt deep-sea warming, paleoceanographic changes and benthic extinctions at the end of the Palaeocene. Nature, 353: 225-229.

Kopciowski, R., Zimnal, Z., Jankowski, L., Szymakowska, F., 2014. Szczegółowa Mapa Geologiczna Polski, 1:50 000, arkusz Gorlice (in Polish). Państwowy Instytut Geologiczny, Warszawa.

Koszarski, L., 1966. Szczegółowa Mapa Geologiczna Polski, Region Karpat i Przedgórza, wydanie tymczasowe, 1:50 000, arkusz Rzepiennik (in Polish). Wyd. Geol., Warszawa.

Koszarski, L., Kuciński, T., 1965. Szczegółowa Mapa Geologiczna Polski, Region Karpat i Przedgórza, wydanie tymczasowe, 1:50 000, arkusz Wojnicz (in Polish). Wyd. Geol., Warszawa.

Koszarski, L., Żytko, K., 1966. Szczegółowa Mapa Geologiczna Polski, Region Karpat i Przedgórza, wydanie tymczasowe, 1:50 000, arkusz Jasło (in Polish). Wyd. Geol., Warszawa.

Koszarski, L., Kuciński, T., Szymakowska, F., 1964. Szczegółowa Mapa Geologiczna Polski, Region Karpat Przedgórza, wydanie tymczasowe, 1:50 000, arkusz Pilzno (in Polish). Wyd. Geol., Warszawa.

Książkiewicz, M., 1932. Der Bau der randlichen Wadowicer Beskiden und ihr Verhältnis zum Vorlande (in Polish with German summary). Rocznik Polskiego Towarzystwa Geologicznego, 8: 49-96.

Książkiewicz, M., 1951. Objaśnienia do Ogólnej Mapy Geologicznej Polski, 1:50 000, arkusz Wadowice (in Polish). Wyd. Geol., Warszawa.

Książkiewicz, M., 1962. Atlas geologiczny Polski, Zagadnienia stratygraficzno-facjalne. Kreda i starszy trzeciorzęd polskich Karpatach zewnętrznych (in Polish). Wyd. Geol., Warszawa.
Książkiewicz, M., 1965. Les cordilleres dans les mers crétacées et paléogčnes des Carpathes du Nord (in French). Bulletin de la Société Géologique de France, 7: 75-97.

Książkiewicz, M., ed., 1972. Geological Atlas of Poland 1:600 000. Stratigraphic and facial problems. Fasc. 13. Cretaceous and Early Tertiary in the Polish External Carpathians. Instytut Geologiczny, Warszawa.

Książkiewicz, M., 1974a. Szczegółowa Mapa Geologiczna Polski, 1:50 000, arkusz Sucha Beskidzka (in Polish). Wyd. Geol., Warszawa.

Książkiewicz, M., 1974b. Objaśnienia do Szczegółowej Mapy Geologicznej Polski, 1:50 000, arkusz Sucha Beskidzka (in Polish). Wyd. Geol., Warszawa.

Książkiewicz, M., 1977. The tectonics of the Carpathians. In: Geology of Poland, Volume IV, Tectonics (ed. W. Pożaryski): 476-620. Wyd. Geol., Warszawa.

Kuciński, T., 1965. Szczegółowa Mapa Geologiczna Polski, Region Karpat i Przedgórza, wydanie tymczasowe, 1:50 000, arkusz Tuchów (in Polish). Wyd. Geol., Warszawa.

Kuhnt, W., Holbourn, A., Zhao, Q., 2002. The early history of the South China Sea: evolution of Oligocene - Miocene deep water environments. Revue de Micropaleontologie, 45: 99-159.

Lear, C.H., Bailey, T.R., Pearson, P.N., Coxall, H.K., Rosenthal, Y., 2008. Cooling and ice growth across the Eocene-Oligocene transition. Geology, 36: 251-254.

Leszczyński, S., 1981. Ciężkowice sandstones of the Silesian Unit in Polish Carpathians: a study of coarse-clastic sedimentation in deep water. Annales Societatis Geologorum Poloniae, 51: 435-502.

Leszczyński, S., 1996. Origin of lithological variation in the sequence of the Sub-Menilite Globigerina Marl at Znamirowice (Eocene-Oligocene transition, Polish Outer Carpathians). Annales Societatis Geologorum Poloniae, 66: 245-267.

Leszczyński, S., 1997. Origin of the Sub-Menilite Globigerina Marl (Eocene-Oligocene transition) in the Polish Outer Carpathians. Annales Societatis Geologorum Poloniae, 67: 367-427.

Leszczyński, S., Radomski, A., 1994. Objaśnienia do Szczegółowej Mapy Geologicznej Polski, 1:50 000, arkusz Ciężkowice (in Polish). Wyd. Geol., Warszawa.

Lexa, J., Elecko, M., Mello, J., Polak, M., Potfaj, M., Vozar, J., eds., 2000. Geological Map of Western Carpathians and adjacent areas. Geological Survey of Slovak Republic, Bratislava.

Lourens, L.J., Sluijs, A., Kroon, D., Zachos, J.C., Thomas, E., Röhl, U., Bowles, J., Raffi, I., 2005. Astronomical pacing of late Palaeocene to early Eocene global warming events. Nature, 435: 1083-1087.

Mahel', M., ed., 1974. Tectonics of the Carpathian-Balkan Regions: Explanations to the Tectonic Map of the Carpathian-Balkan Regions and their Foreland. Štátny geologický ústav Dionýza Štúra, Bratislava.

Menčík, E., Tyráček, J. 1985. Přehledná geologická mapa Beskyd a Podbeskydské pahorkatiny, 1:100 000 (in Czech). Cesky Geologicky Urad, Ustredni Ustav Geologicky, Praha.

Miller, K.G., 1992. Middle Eocene to Oligocene stable isotopes, climate, and deep-water history: The Terminal Eocene Event? In: Eocene-Oligocene Climatic and Biotic Evolution (eds. D. Prothero and W.A. Berggren): 160-177. Princeton University Press, Princeton.

Miller, K.G., Janesek, T.R., Katz, M.E., Keil, D.J., 1987. Abyssal circulation and benthic foraminiferal changes near Paleocene/Eocene boundary. Paleoceanography, 2: 741-761.

Miller, K.G., Kominz, M.A., Browning, J.V., Wright, J.D., Mountain, G.S., Katz, M.E., Sugarman, P.J., Cramer, B.S., Christie-Blick, N., Pekar, S.F., 2005. The Phanerozoic record of global sea-level change. Science, 310: 1293-1298.

Morgiel, J., Olszewska B., 1981. Biostratigraphy of the Polish External Carpathians based on agglutinated foraminifera. Micropaleontology, 27: 1-30.

Morgiel, J., Szymakowska, F., 1978. Stratigraphy of the Paleocene and Eocene of the Skole Unit (in Polish with English summary). Biuletyn Instytutu Geologicznego, 310: 39-171. 
Neagu, T., Popescu, D.P., Crihan, L.M., Popescu, G., 2011. Upper Eocene agglutinated foraminifera from Buciumeni section (lalomita Valley, Dambovita District, Romania). Grzybowski Foundation Special Publication, 16: 151-172.

Nescieruk, P., Paul, Z., Ryłko, W., Szymakowska, F., Wójcik, A., Żytko, K., 1995. Szczegółowa Mapa Geologiczna Polski, 1:200 000, arkusz Jasło (in Polish). Wydawnictwo Kartograficzne PAE SA., Warszawa.

Nescieruk, P., Paul, Z., Rączkowski, W., Szymakowska, F., Wójcik, A., 1996. Objaśnienia do Szczegółowej Mapy Geologicznej Polski, 1:200 000, arkusz Jasło (in Polish). Państwowy Instytut Geologiczny, Warszawa.

Nowak, J., 1927. Esquisse de la tectonique de la Pologne (in Polish with French summary). Komitet Organizacyjny II Zjazdu Geografów i Etnografów, Kraków.

Nowak, W., 1963. Szczegółowa Mapa Geologiczna Polski, Region Karpat i Przedgórza, wydanie tymczasowe, 1:50 000, arkusz Bielsko-Biała (in Polish). Wyd. Geol., Warszawa.

Nowak, W., 1964. Szczegółowa Mapa Geologiczna Polski, Region Karpat i Przedgórza, wydanie tymczasowe, 1:50 000, arkusz Lachowice (in Polish). Wyd. Geol., Warszawa.

Olszewska, B., 1980. Foraminiferal biostartigraphy of Upper Cretaceous and Palaegene sediments of the central part of the Dukla Unit. Biuletyn Instytutu Geologicznego, 326: 59-107.

Olszewska, B., 1981. Paleoecological characteristics of small foraminifers from the Lower Eocene claystones with clinoptylolite from the Polish part of Outer Carpatians (in Polish with English summary). Biuletyn Instytutu Geologicznego, 331: 69-82.

Olszewska, B., 1983. A contribution to the knowledge of planktonic foraminifers of the Globigerina Submenilite Marls in the Polish Outer Carpathians (in Polish with English summary). Kwartalnik Geologiczny, 27 (3): 547-570.

Olszewska, B., 1984. Benthonic foraminifera of the Sub-Menilite Globigerina Marls of Polish Outer Carpathians (in Polish with English summary). Prace Instytutu Geologicznego, 110: 1-33.

Olszewska, B., 1997. Foraminiferal biostratigraphy of the Polish Outer Carpathians; a record of basin geohistory. Annales Societatis Geologorum Poloniae, 67: 325-337.

Olszewska, B., Malata, E., 2006. Palaenvironmental and palaeobathymetric analysis of microfossil assemblages of the Polish Outer Carpathians (in Polish with English summary). In: Paleotectonic evolution of the Outer Carpathian and Pienniny Klippen Belt basins (eds. N. Oszczypko, A. Uchman and E. Malata), 61-84, ING UJ, Kraków.

Olszewska, B., Odrzywolska-Bieńkowa, E., Giel, M.D. Pożaryska, K., Szczechura, K., 1996. Rząd Foraminiferida Eichwald, 1830. In: Budowa geologiczna Polski. Atlas skamieniałości przewodnich i charakterystycznych. Kenozoik. Trzeciorzęd. Paleogen. Volume III, part 3a (eds. L. Malinowska and M. Piwocki): 45-215. Wyd. Geol., Warszawa.

Ortiz, S., Thomas, E., 2006. Lower-middle Eocene benthic foraminifera from the Fortuna Section (Betic Cordillera, south-eastern Spain). Micropaleontology, 52: 97-150.

Osterman, L.E., Spiegler, D., 1996. Agglutinated benthic foraminiferal biostratigraphy of Sites 909 and 913, northern North Atlantic. Proceedings of the Ocean Drilling Program Scientific Results, 151: 169-185

Oszczypko, N., 2006. Position of the Polish Outer Carpathians in the Alpine arc and their stages of development (in Polish with English summary). In: Paleotectonic Evolution of the Outer Carpathian and Pienniny Klippen Belt Basins (eds. N. Oszczypko, A Uchman and E. Malata): 5-18. ING UJ, Kraków.

Oszczypko, N., Wójcik, A., 1993. Objaśnienia do Szczegółowej Mapy Geologicznej Polski, 1:50 000, arkusz Nowy Sącz (in Polish). Wyd. Geol., Warszawa

Oszczypko, N., Uchman, A., Malata, E., 2006. Palaeotectonic evolution of the Outer Carpathian and Pieniny Klippen Belt Basins. Instytut Nauk Geologicznych Uniwersytetu Jagiellońskiego, Kraków.
Pak, D.K., Miller, K.G., 1992. Paleocene to Eocene benthic foraminiferal isotopes and assemblages: implications for deep-water circulation. Paleoceanography, 7: 405-422.

Pälike, H., Lyle, M.W., Nishi, H., Raffi, I., Ridgwell, A., Gamage,K., Klaus, A., Acton, G., Anderson, L., Backman, J., Baldau, F.J., Beltran, C., Bohaty, S.M., Bown, P., Busch, W., Channel, J.E.T., Chun, C.O.J., Delaney, M., Dewangan, P., Dunkley Jones, T., Edgar, K.M., Evans, H., Fitch, P., Foster, G.L., Gussone, N., Hasegawa, H., Hathorne, E.C., Hayashi, H., Herrle, J.O., Holbourn, A., Hovan, S., Hyeong, K., lijima, K., Ito, T., Kamikuri, S., Kimoto, K., Kuroda, J., Leon-Rodriguez, L., Malinverno, A., Moore Jr., T.C., Murphy,B.H., Murphy, D.P., Nakamura, H., Ogane, K., Ohneiser, C., Richter, C., Robinson, R., Rohling, E.J., Romero, O., Sawada, K., Scher, H., Schneider, L., Sluijs, A., Takata, H., Tian, J., Tsujimoto, A., Wade, B.S., Westerhold, T., Wilkens, R., Williams, T., Wilson, P.A., Yamamoto, Y., Yamamoto, S., Yamazakl, T., Zeebe, R.E., 2012. A Cenozoic record of the equatorial Pacific carbonate compensation depth. Nature, 488: 609-614.

Pardo, A., Keller, G., Oberhänsli, H., 1999. Paleoecologic and paleoceanographic evolution of the Tethyan realm during the Paleocene-Eocene transition. Journal of Foraminiferal Research, 29: 37-57.

Paul, K., Tietze, E., 1879. Neue Studien in der Sandsteinzone der Karpathen. Jahrbuch der Kaiserlich-königlichen geologischen Reichsanstalt, 29: 189-304.

Paul, Z., 1991. Szczegółowa Mapa Geologiczna Polski, 1:50 000 arkusz Grybów (in Polish). Wyd. Geol., Warszawa.

Paul, Z., 1993. Objaśnienia do Szczegółowej Mapy Geologicznej Polski, 1:50 000, arkusz Grybów (in Polish). Wyd. Geol., Warszawa.

Paul, Z., Ryłko, W., 1987. Objaśnienia do Szczegółowej Mapy Geologicznej Polski, 1:50 000, arkusz Rabka (in Polish). Wyd. Geol., Warszawa.

Paul, Z., Rączkowski, W., Ryłko, W., Wójcik A., 1996. Objaśnienia do Szczegółowej Mapy Geologicznej Polski, 1:50 000, arkusz Myślenice (in Polish). Wyd. Geol., Warszawa.

Pearson, P.N., Olsson, R.K., Huber B.T., Hemleben, C. Berggren, W.A., 2006. Atlas of Eocene planktonic foraminifera. Cushman Foundation for Foraminiferal Research, Special Publication, 41: 1-513.

Picha, F., Stráník, Z.,Krejčí, 2006. Geology and hydrocarbon resources of the Outer West Carpathians and their foreland, Czech Republic. AAPG Memoir, 84: 49-175.

Połtowicz, S., 1985. The Grybów unit to the south of Limanowa (Polish West Carpathians) (in Polish with English summary). Annales Societatis Geologorum Poloniae, 55: 77-104.

Rajchel, J., 1990. Lithostratigraphy of the Upper Palaeocene and Eocene sediments from the Skole Unit (in Polish with English summary). Geologia - Kwartalnik AGH, 48: 1-123.

Ryłko, W., 2004. Karpaty (in Polish). In: Budowa geologiczna Polsk (eds. T. Peryt and M. Piwocki): 271-321. Państwowy Instytut Geologiczny, Warszawa.

Savian, J., Jovane, L., Coccioni, R., Frontalini, F., Bancalŕ, G., Luciani, V., Bohaty, S., Catanzariti, R., Trindade, R., 2011. Middle Eocene to Early Oligocene climate: preliminary age to biostratigraphic data from Monte Cagnero Section, Central Italy. Latinmag Letters, Special Issue, 1: 1-6.

Sikora, W., 1963. Szczegółowa Mapa Geologiczna Polski, Region Karpat i Przedgórza, wydanie tymczasowe, 1:50 000, arkusz Grybów (in Polish). Wyd. Geol., Warszawa

Sikora, W., 1964. Szczegółowa Mapa Geologiczna Polski, Region Karpat i Przedgórza, wydanie tymczasowe, 1:50 000, arkusz Gorlice (in Polish). Wyd. Geol., Warszawa.

Skoczylas-Ciszewska, K., 1952. Budowa geologiczna brzegu Karpat w okolicy Bochni (in Polish). Biuletyn Instytutu Geologicznego, 77: 57-77.

Skoczylas-Ciszewska, K., 1954. Szczegółowa Mapa Geologiczna Polski, 1:50 000, arkusz Brzesko (in Polish). Wyd. Geol., Warszawa. 
Skoczylas-Ciszewska, K., 1964. Szczegółowa Mapa Geologiczna Polski, Region Karpat i Przedgórza, wydanie tymczasowe, 1:50 000, arkusz Brzesko (in Polish). Wyd. Geol., Warszawa.

Skoczylas-Ciszewska, F., Burtan, J., 1954. Szczegółowa Mapa Geologiczna Polski, 1:50 000, arkusz Bochnia (in Polish). Wyd. Geol., Warszawa.

Sluijs, A., Zeebe, R.E., Bijl, P.K., Bohaty, S.M., 2013. A middle Eocene carbon cycle conundrum. Nature Geoscience, 6 : 429-434.

Słomka, T., 1995. Deep-marine siliciclastic sedimentation of the Godula beds, Carpathians (in Polish with English summary). Prace Geologiczne, 139: 1-132.

Słomka, T., Malata, T., Leśniak, T., Oszczypko, N., Poprawa, P., 2006. Evolution of the Silesian and Subsilesian basins (in Polish with English summary). In: Paleotectonic Evolution of the Outer Carpathian and Pienniny Klippen Belt Basins (eds. N. Oszczypko, A. Uchman and E. Malata): 111-126. ING UJ, Kraków.

Stap, L., Lourens, L.J., Thomas, E., Sluijs, A., Bohaty, S., Zachos, J.C., 2010. High-resolution deep-sea carbon and oxygen isotope records of Eocene Thermal Maximum 2 and $\mathrm{H} 2$. Geology, 38: 607-610.

Szymakowska, F., 1964. Szczegółowa Mapa Geologiczna Polski, Region Karpat i Przedgórza, wydanie tymczasowe, 1:50 000, arkusz Bielsko-Biała (in Polish). Wyd. Geol., Warszawa.

Szymakowska, F., 1979. Geology of the southern limb of the Gorlice fold between Gorlice and Kryg (Polish Middle Carpathians) (in Polish with English summary). Rocznik Polskiego Towarzystwa Geologicznego, 49: 85-103.

Szymakowska, F., Wójcik, A., 1981. Szczegółowa Mapa Geologiczna Polski, 1:50 000, arkusz Jedlicze (in Polish). Wyd. Geol., Warszawa.

Szymakowska, F., Żytko, K, 1964. Szczegółowa Mapa Geologiczna Polski, Region Karpat i Przedgórza, wydanie tymczasowe, 1:50 000, arkusz Kalwaria Zebrzydowska (in Polish). Wyd. Geol., Warszawa.

Szymakowska, F., Wójcik, A., 1992. Objaśnienia do Szczegółowej Mapy Geologicznej Polski, 1:50 000, arkusz Jedlicze (in Polish) Wyd. Geol., Warszawa.

Ślączka, A., 1959. Stratigraphy of the Bystra scale (Middle Carpathians) (in Polish with English summary). Biuletyn Instytutu Geologicznego, 131: 203-286.

Ślączka, A., 1971. Geology of the Dukla unit (Polish flysch Carpathians) (in Polish with English summary). Biuletyn Instytutu Geologicznego, 63: 1-97.

Ślączka, A., Kaminski, M.A., 1998. A guidebook to excursions in the Polish Flysch Carpathians: Grzybowski Foundation, Special Publication, 6: 1-171.

Ślączka, A., Kruglow, S., Golonka, J., Oszczypko, N., Popadyuk, I., 2006. The general geology of the Outer Carpathians, Poland, Slovakia, and Ukraine. AAPG Memoir, 84: 221-258.

Świdziński, H., 1948. Słownik stratygraficzny północnych Karpat fliszowych (in Polish). Biuletyn Państwowego Instytutu Geologicznego, 37: 1-124.

Świdziński, H., 1950. Stróże Scale near Grybów (Middle Carpathians) (in Polish with English summary). Biuletyn Państwowego Instytutu Geologicznego, 59: 1-70.

Świdziński, H., 1973. The geological structure of the region Ropica-Siary Górne (in Polish with English summary). Prace Geologiczne, 80: 63-76.

Thomas, E., 1998. The biogeography of the Late Paleocene benthic foraminiferal extinction. In: Late Paleocene-Early Eocene Biotic and Climatic Events in the Marine and Terrestrial Records (eds. M.P. Abury, S.G. Lucas and W.A. Berggren): 214-243. Columbia University Press, New York.

Thomas, E., Shackleton, N.J., 1996. The Paleocene-Eocene benthic foraminiferal extiction and stable anomalies. GSA Special Publications, 101: 401-411.

Tjalsma, R.C., Lohman, G.P., 1983. Paloeocene-Eocene bathyal and abyssal benthic foraminifera from the Atlantic Ocean. Microplaleontology, Special Publication, 4: 1-90.
Unrug, R., 1979. Palinspastic reconstruction of the Carpathian before the Neogene tectogenesis. Rocznik Polskiego Towarzystwa Geologicznego, 49: 3-21.

Waśkowska, A., 2011a. Response of Early Eocene deep-water benthic foraminifera to volcanic ash falls in the Polish Outer Carpathians. Palaeogeography, Palaeoclimatology, Palaeoecology, 305: 50-64

Waśkowska, A., 2011b. The Early Eocene Saccamminoides carpathicus assemblage in the Outer Flysch Carpathians. Grzybowski Foundation Special Publication, 16: 331-341.

Waśkowska, A., 2012. Monospecific foraminiferal assemblages with Trochammina in Early Eocene Carpathian deposits (Silesian unit, Polish Outer Carpathians). In: 13th Czech-Slovak-Polish Paleontological Conference (eds. S. Hladilova, N. Dolakova and O. Dostal): 70. Mendel Museum, Brno.

Waśkowska, A., 2014a. Bulbobaculites gorlicensis n. sp. - a new agglutinated foraminifera from Eocene of flysch Carpathians. Micropaleontology, 60: 465-473.

Waśkowska A., 2014b. The Eocene Hieroglyphic beds and Green shales in the Rożnów Lake area (Silesian Nappe, Outer Carpathians) - facies development and biostratigraphy. Geology, Geophysics and Environment, 40: 5-26.

Waśkowska, A., 2014c. Selective agglutination of tourmaline grains by foraminifera in deep-water flysch environment (Eocene Hieroglyphic Beds, Silesian Nappe, Polish Outer Carpathians). Geological Quarterly, 58 (2): 337-352.

Waśkowska, A., 2015a. Small-sized Trochammina assemblages in deep-water Eocene flysch deposits (Outer Carpathians, Poland) and their palaeoecological implications. Journal of Micropalaeontology, 34: 1-19, doi: 10.1144/jmpaleo2013-013

Waśkowska, A., 2015b. Development and biostratigraphy of Hieroglyphic beds in Szczyrzyc Depression; "Black Eocene" deposits as component of Hieroglyphic beds (Silesian Nappe, Outer Carpathians, Poland). Annales Societatis Geologorum Poloniae, 85.

Waśkowska-Oliwa, A., 2000. Biostratigraphic and paleoecologic interpretation of the agglutinated foraminifera assemblages of the Paleocene-Middle Eocene Ideposits of the Magura Nappe in the Sucha Beskidzka (Outer Carpathians) (in Polish with English summary). Przeglad Geologiczny, 48: 331-336.

Waśkowska-Oliwa, A., 2005. Foraminiferal paleodepth indicators from the lower Palaeogene deposits of the Subsilesian Unit (Polish Outer Carpathians). Studia Geologica Polonica, 124: 297-324.

Waśkowska-Oliwa, A., 2007. Problem biostratygrafii otwornicowej paleocenu w głębokowodnych osadach basenów karpackich (in Polish). In: 8 Palentologicka Konferencja - Zbornik Abstaktov (ed. A. Zlinska): 106-107. Statny geologicki ustav Dioniza Stura, Bratislava.

Waśkowska-Oliwa, A., 2008. Haplophragmoides nauticus Kender Kaminski \& Jones in the Eocene of the Flysch Carpathians. Grzybowski Foundation Special Publication, 14: 63-64.

Waśkowska, A., Cieszkowski, M., 2014. Biostratigraphy and depositional anatomy of a large olistostrome in the Eocene $\mathrm{Hi}$ eroglyphic Formation of the Silesian Nappe, Polish Outer Carpathians. Annales Societatis Geologorum Poloniae, 84: 51-70.

Waśkowska-Oliwa, A., Cieszkowski, M., Stadnik, R., Chodyń, R., 2008. Warstwy hieroglifowe serii ślaskiej na SE od Dobczyc, zachodnie Karpaty zewnętrzne (in Polish). In: Pierwszy Kongres Geologiczny (ed. G. Haczewski): 127. Polskie Towarzystwo Geologiczne, Kraków.

Wdowiarz, S., Zubrzycki, A., Frysztak-Wołkowska, A., 1991 Objaśnienia do Szczegółowej Mapy Geologicznej Polski, 1:50 000, arkusz Rymanów (in Polish). Wyd. Geol., Warszawa.

Wójcik, A., Rączkowski, W., 1994. Objaśnienia do Szczegółowej Mapy Geologicznej Polski, 1:50 000, arkusz Osielec (in Polish). Wyd. Geol., Warszawa.

Wójcik, A., Jasionowicz, J., Szymakowska, F., 1993a. Szczegółowa Mapa Geologiczna Polski, 1:50 000, arkusz Jasło (in Polish). Wyd. Geol., Warszawa. 
Wójcik, A., Jasionowicz, J., Szymakowska, F., 1993b. Objaśnienia do Szczegółowej Mapy Geologicznej Polski, 1:50 000, arkusz Jasło (in Polish). Wyd. Geol., Warszawa.

Zachos, J.C., Pagani, M., Sloan, L., Thomas, E., Billups, K., 2001. Trends, rhythms, and aberrations in global climate $65 \mathrm{Ma}$ to present. Science, 292: 686-693.

Zachos, J.C., Schouten, S., Bohaty, S., Quattlebaum, T., Sluijs, A., Brinkhuis, H.,Gibbs, S.J., Bralower, T.J., 2006. Extreme warming of mid-latitude coastal ocean during the Paleocene-Eocene thermal maximum: inferences fromTEX86 and isotope data. Geology, 34: 737-740.

Zachos, J.C., Dickens, G.R., Zeebe, R.E., 2008. An early Cenozoic perspective on greenhouse warming and carbon-cycle dynamics. Nature, 451: 279-283.
Zachos, J.C., McCarren, H., Murphy, B., Röhl, U., Westerhold, T., 2010. Tempo and scale of late Paleocene and early Eocene carbon isotope cycles: implications for the origin of hyperthermals. Earth and Planetary Science Letters, 299: 242-249.

Żytko, K., 1963. Szczegółowa Mapa Geologiczna Polski, Region Karpat i Przedgórza, wydanie tymczasowe, 1:50 000, arkusz Milówka (in Polish). Wyd. Geol., Warszawa.

Żytko, K., Gucik, S., Oszczypko, N., Zając, R., Garlicka, I., Nemčok, J., Eliáš, M., Menčik, E., Dworak, J., Stranik, Z., Rakuš, M., Matejovska, O., 1989. Geological map of the Western Outer Carpathians and their foreland without Quaternary formations. In: Geological Atlas of the Western Carpathians and Their Foreland (eds. D. Poprawa and J. Nemčok). Państwowy Instytut Geologiczny, Warszawa. 